Primljeno: 15.4 .2019 .

Prihvaćeno: 6.6.2019.

DOI: https://doi.org/10.36506/av.62.6

\title{
Mario Stipančević
}

Hrvatski državni arhiv

Zagreb, Hrvatska

mstipancevic@arhiv.hr

\section{MLADA JUGOSLAVIJA - TERORISTIČKA ISPOSTAVA ZAGREBAČKE POLICIJE}

\author{
UDK 351.74(497.1)“1918/1941“(091) \\ 323.281(497.5)“1918/1941“(091)
}

Izvorni znanstveni rad

Postojanje "pomoćne Bedekovićeve čete" zadužene za provodenje prljavih poslova u korist policije po nalozima beogradskih vlastodržaca zabilježeno je u svega nekoliko historiografskih tekstova i rijetkim sjećanjima sudionika zlosretnih dogadaja $u$ zagrebačkom društvenom mikrokozmosu nakon uspostave šestosiječanjske diktature. Prilog ima za cilj rasvijetliti istinitost spomenutih navoda. Postojanje gotovo terorističke organizacije na temelju arhivskih vrela povezano je s Omladinskim drustvom Mlada Jugoslavija, koje je, osim izvanjskoga i zakonitoga okvira, u svojem djelovanju skrivalo naličje provoditelja državnoga nasilja prema onodobnim političkim neistomišljenicima.

Ključne riječi: Omladinsko društvo Mlada Jugoslavija; Janko Bedeković; Kraljevina Jugoslavija; politički teror

\section{Uvod}

"Kraljevina čuvara«, kako je u naslovu opsežne studije o represivnom aparatu monarhističke Jugoslavije nazvana onodobna zajednica, ${ }^{1}$ uistinu je počivala na obilato financiranom i od državnih tijela blagoslovljenom teroru. Međutim, za

\footnotetext{
$1 \quad$ Hrvoje Čapo, Kraljevina čuvara: Represivni aparat monarhističke Jugoslavije na području hrvatskih zemalja (1918.-1941.) (Zagreb: Hrvatski institut za povijest, 2015).
} 
njegovo provođenje nisu bile dovoljne samo uobičajene poluge vlasti poput policije, oružništva i razgranate agentsko-špijunske mreže. Kralja i državu valjalo je štititi i plaćenim doušnicima, prokazivačima i batinašima. Neprijatelja režima uistinu je bilo mnogo, a takve su društvene prilike pogodovale zagrebačkomu redarstveniku Janku Bedekoviću i njegovoj policijsko-doušničko-agentskoj podružnici za javnost uobličenoj u unitarističkom Omladinskom društvu Mlada Jugoslavija.

Bedeković se u historiografskim tekstovima spominjao često te bi se samo za puko nabrajanje publikacija u kojima je naveden morale potrošiti desetine stranica. ${ }^{2} \mathrm{~Pa}$ ipak, sve donedavno o njemu nije postojala cjelovitija biografija, ${ }^{3}$ iako je kao malotko ranije u društvenu zbilju Zagreba i Hrvatske urezao duboku traumu, postavši sinonimom policijske bestijalnosti starojugoslavenskoga režima prema najširim slojevima stanovništva. Predani progonitelj protivnika beogradskih vlastodržaca bez obzira na politički predznak preminuo je dovoljno rano da ostane nekažnjen i od ustaških i od komunističkih vlasti, čije je pripadnike, među ostalima, ranije nemilosrdno progonio. Možda je upravo zbog toga bio zaboravljen te time pošteđen (i) historiografskih prosudbi. Slično se dogodilo i batinašima iz Mlade Jugoslavije.

Historijat institucionaliziranoga nasilja prema neistomišljenicima režima, dakako, u Hrvatskoj nije započeo s utemeljenjem Mlade Jugoslavije. Dovoljno je prisjetiti se utjecajnije i razgranatije Organizacije jugoslavenskih nacionalista, ekstremno nacionalističke i terorističke organizacije utemeljene 1921. u okviru desnoga krila Demokratske stranke sa zadatkom »očuvanja državnog i narodnog jedinstva«, borbe protiv komunizma te, posebice, pripadnika hrvatskoga nacionalnog pokreta. ${ }^{4}$ Bilo bi korisno usporediti Orjunu i Mladu Jugoslaviju, posebice ako se uzme u obzir da se potonja vremenski (a djelomice i načinom rada te ciljevima) nastavlja na djelovanje prve, ugašene uvođenjem diktature početkom 1929. godine. To na ovom mjestu, zbog opsega koji zahtjeva analiza takve vrste, nažalost nije moguće.

\footnotetext{
2 Usp. podatke Ivane Dobrivojević u bilješci 16 i Nade Kisić-Kolanović u bilješci 19, te, primjerice, vremenski pogrešne podatke o Bedekovićevom ravnanju zagrebačkom policijom koje donosi Bosiljka Janjatović, Politički teror u Hrvatskoj 1918.-1935. (Zagreb: Hrvatski institut za povijest, Dom i Svijet, 2002), str. 246, bilj. 527.

3 Mario Stipančević, "Vampir iz Petrinjske: Obris portreta Janka Bedekovića," Gordogan 15, br. 35-36 (2017): str. 104-128.

4 Slaven Ravlić, Hrvatska enciklopedija: 8: O-Pre (Zagreb: Leksikografski zavod Miroslav Krleža, 2006), s. v. Orjuna; Stevo Đurašković, "Ideologija Organizacije jugoslovenskih nacionalista," Časopis za suvremenu povijest 43, br. 1 (2011): str. 231-232. Za više o Orjuni usp. Ivan J. Bošković, Orjuna: Ideologija i književnost (Zagreb: Hrvatska sveučilišna naklada, 2002), osobito poglavlja "3. Od Jugoslavenske Napredno-Nacionalne Omladine do Orjune” (str. 84-93) i “4. Ideologija Orjune” (str. 94-129).
} 


\section{Janko Bedeković - gospodar iza zastora}

Zbog istoga je razloga i o zloglasnom zagrebačkom policajcu navedeno samo nekoliko temeljnih informacija, u nadi da će biti dostatne za razumijevanje središnje teme teksta koji čitatelj ima pred sobom. Mjesto i najbliža društvena okolina u kojoj je Bedeković rođen nisu davali naslutiti njegove kasnije karakterne značajke. Na svijet je došao kao potomak starih turopoljskih plemenitaških obitelji s očeve (de genere Kobilich) i majčine strane (Modić de Nagy Mlaka et Kurilovecz). ${ }^{5}$ Svjedodžbu zrelosti stekao je 1903., a godinu kasnije upisao Pravni i državoslovni fakultet u Zagrebu. Prvi je državni ispit položio 1904., drugi 1906., a pravoslovni 1909. godine. Nešto kasnije iste godine dao je i državni znanstveni ispit, a u listopadu 1910., položivši rigoroz, postao je doktor prava. ${ }^{6}$ Čini se da je barem jedan semestar studija odslušao na pravnom fakultetu praškoga sveučilišta. ${ }^{7}$ Već početkom 1909. imenovan je "vladinim perovodnim vježbenikom" i dodijeljen Kr. redarstvenom povjerenstvu za Grad Zagreb. U studenom iste godine premješten je na službu u Zagrebačku kotarsku oblast, gdje se zadržao do 1912., kada je ponovno vraćen na policijske dužnosti, taj put u gradski Odjel za unutrašnje poslove. Od listopada 1912. do listopada 1913. djelovao je u karlovačkom Redarstvenom povjereništvu, nakon čega je nanovo pridijeljen zagrebačkomu redarstvu. ${ }^{8} \mathrm{U}$ policijskim krugovima poznatijim je postao u svibnju 1914. zbog tobožnjega sprječavanja atentata na bana Ivana Skerlecza i uhićenja napadača, slušatelja zagrebačke Trgovačke akademije i navodnoga pripadnika revolucionarne omladine Jakoba Schäffera u vrijeme posjeta nadvojvode Leopolda Salvatora Zagrebu. ${ }^{9}$

Tijekom Prvoga svjetskog rata postao je nemilosrdan progonitelj protivnika Monarhije. Zbog opetovanih disciplinskih prijestupa u rujnu 1916. nanovo je premješten u civilnu službu, taj puta pri Kr. kotarskoj oblasti u Velikoj Gorici, gdje je dočekao kraj svjetskoga sukoba i promjenu državnoga uređenja. ${ }^{10}$ Početkom 1919. namješten je za upravitelja kotarske oblasti u Stubici, devet mjeseci kasnije na istu dužnost u Ogulinu, a 1920. iz kotarske je premješten u županijsku oblast u istom gradu. Sljedeće godine, sada kao gorljivi centralist i unitarist, postavljen je na čelo kotarske oblasti na Sušaku, zatim na isto mjesto u Crikvenici, da bi se krajem godine ponovno vratio na Sušak u svojstvu pomoćnika povjerenika grada sa zadu-

\footnotetext{
5 HR-HDA-1448. Zbirka mikrofilmova matičnih knjiga i obitelji, ZM-34C/229, Brdovec, MKR 1878.-1887.

6 HR-HDA-890. Zbirka personalija, br. 1258; Stipančević, "Vampir iz Petrinjske," str. 104.

7 Usp. potvrdu praškoga pravnog fakulteta od 8. srpnja 1908. u privatnom posjedu Tomislava Kallaya (Frankopanska br. 29, Zagreb), Jankova nasljednika po liniji njegove sestre Ljubice Amalije.

8 HR-HDA-890. Zbirka personalija, br. 1258; Stipančević, "Vampir iz Petrinjske," str. 105.

9 Usp. Josip Horvat, Pobuna omladine 1911-1914 (Zagreb: Udruga za kulturu Gordogan, 2006), str. 127-267; "K 'atentatu' na bana," Ilustrovani list, br. 22 (30. svibnja 1914.): str. 515; Stipančević, "Vampir iz Petrinjske," str. 105-106.

10 HR-HDA-890. Zbirka personalija, br. 1258; Stipančević, "Vampir iz Petrinjske," str. 111.
} 


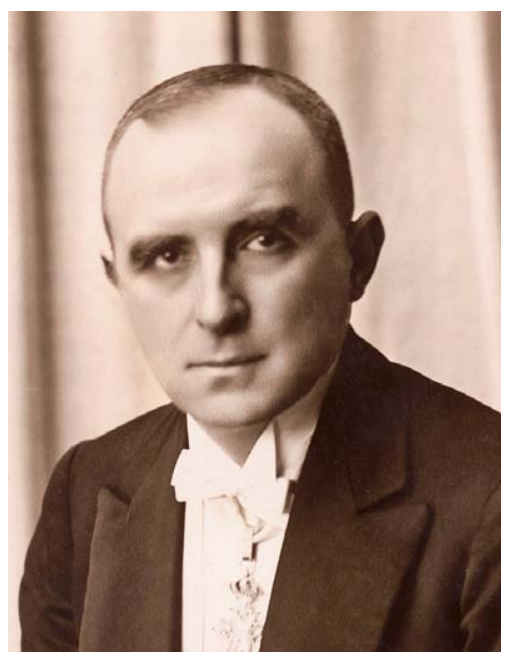

Slika 1. "Sitan, no proporcionalno graden, s licem koje je možda u nijansama asimetrije oštrih dugoljastih crta odavalo neuravnoteženost. Samo su mu oči bile čudne: sitne, nemirne kao u vjeverice." Janko Bedeković 1930. godine. Iz fotoalbuma u posjedu Dobrovoljnoga vatrogasnog društva Donja Lomnica.

ženjem nadzora i upravljanja gradskim redarstvom. U rujnu 1924. namješten je za upravitelja kotarske oblasti u Požegi, a svega dva mjeseca kasnije postavljen je za upravitelja Kr. redarstvenoga ravnateljstva u Zagrebu. ${ }^{11}$

Prvi Bedekovićev mandat na čelu policije obilježilo je uhićenje oporbenoga prvaka Stjepana Radića u siječnju 1925. godine. ${ }^{12}$ Ulazak HSS-a u vladu zajedno s radikalima vjerojatno je razlog njegove brze smjene $s$ te dužnosti već u srpnju iste godine te imenovanja inspektorom pri Ministarstvu unutarnjih dela $u$ Beogradu. ${ }^{13}$ Tijekom toga se razdoblja u zloglasnom beogradskom zatvoru Glavnjači, ${ }^{14}$ koji je kažnjavanju političkih protivnika služio tijekom pet različitih političkih režima od obrenovićevskoga početkom do komunističkoga sredinom 20. stoljeća, Bedeković najvjerojatnije pripremao za ponovni povratak u Zagreb. Postupke u zatvoru koji je postao metafora neuvijenoga kažnjavanja (političkih) zatočenika glavnoga grada (i države uopće) preslikao je na onaj u Petrinjskoj br. 18 u Zagrebu. Sasvim sigurno ne slučajno. Teror je bio jedan od načina koji je kralj s vojnim krugovima prepoznao kao metodu opstanka Kraljevine. Bilo je

11 HR-HDA-890. Zbirka personalija, br. 1258; Stipančević, "Vampir iz Petrinjske," str. 111, 114-115.

12 Usp. Bedekovićeve dnevne policijske izvještaje velikomu županu Zagrebačke oblasti Ivi Zucconu u: HR-HDA-1363. Grupa XXI, inv. br. 965. U njima, doduše, nije sačuvan onaj o uhićenju vođe hrvatske oporbe u Seljačkom domu, ali i raspoloživi dovoljno svjedoče o angažmanu upravitelja zagrebačke policije u praćenju i uhićenjima istaknutih haesesovaca, kao i njegovoj neposrednoj odgovornosti za Radićevo privođenje. U spomenutom se vrelu može zamijetiti i Bedekovićevo dodvoravanje beogradskim poslodavcima pisanjem i potpisivanjem izvještaja ćirilicom. Usp. Janjatović, Politički teror u Hrvatskoj 1918.-1935., str. 53.

13 HR-HDA-890. Zbirka personalija, br. 1258.

${ }_{14} \mathrm{O}$ simbolici zloglasnoga beogradskog zatvora usp. Rajko Jovanović, Glavnjača kao sistem (Zagreb: Izdanje Zaštite čovjeka, 1928), s predgovorom Miroslava Krleže. 
samo potrebno pronaći provoditelje. Po mogućnosti iz istoga etničkoga korpusa čije je pripadnike valjalo proganjati zbog podizanja glave u znak prosvjeda protiv vlastodržaca i neslaganja s njihovim odlukama.

Iz spomenutih je razloga nedugo nakon uspostave šestosiječanjske diktature Bedeković ponovno vraćen na službu u hrvatsku prijestolnicu, prvo kao pravni referent Zagrebačke oblasti, a od travnja 1929. i direktor zagrebačke policije. ${ }^{15}$ Drugo razdoblje ravnanja zagrebačkim redarstvom obilježio je nezapamćenim terorom i nasiljem prema protivnicima Aleksandrova režima. Od njegove ili od ruke njegovih agenata, doušnika, batinaša i prokazivača stradale su stotine građana. Praćenja, prijetnje i zastrašivanja postali su svakodnevicom. Velika većina sumnjivaca privođena je u Petrinjsku, u kojoj su priznanja o protudržavnoj djelatnosti iznuđivana najbrutalnijim oblicima mučenja. Spočetka uz glasnu glazbu s pohabanih gramofonskih ploča, koja je imala zadaću prigušivanja vriske i zapomaganja zatočenika. Kasnije i bez toga, jer se Bedeković uvjeren u vlastitu moć i kraljevu potporu (s pravom) nije imao koga bojati. Metode mučenja bile su nezamislive. Od premlaćivanja životinjskim žilama, palicama i bokserima do zabijanja čavala, igala i zapaljenih drvenih klinova umočenih u benzin pod nokte, cjelodnevnoga vješanja za noge, batinanja po tabanima, lomljenja prstiju i ekstremiteta, čupanja mesa i stidnih dlaka, vješanja cigala o genitalije, silovanja, skakanja po trbuhu trudnica i dr. Ako su već kojim slučajem izdržali fizičku torturu, psihički slabije zatvorenice i zatvorenici najčešće su tražili izlaz u vješanju, trovanju, skakanju s prozora, pokušaju bijega ili - priznavanju svega što im je optužbom bilo nametnuto na teret. ${ }^{16}$ Tamničarima je, u pravilu, bilo svejedno.

Zbog zasluga u zaštiti kraljeva režima Bedeković je odlikovan Ordenom Beloga orla (1927. i 1929.) i Ordenom Jugoslavenske krune (1932.). ${ }^{17}$ Usprkos činjenici da je još od uhićenja Radića bio među kraljevim miljenicima, u srpnju

15 HR-HDA-890. Zbirka personalija, br. 1258; Stipančević, "Vampir iz Petrinjske," str. 118.

16 Postupke "zloglasnoga Bedekovića« već koncem 1929. opisao je ilegalni komunistički list Proleter osvrćući se na žrtve unutar vlastitih redova. "Godišnjica generalsko-fašističke diktature," Proleter 1, br. 7 (1929): str. 2. O onodobnoj policijskoj torturi usp. Tomislav Jonjić, "Proces Hranilović-Soldin: Prilog poznavanju postanka ustaškog pokreta." U Hrvatska između slobode i jugoslavenstva: Zbornik radova sa znanstvenog skupa održanog 8. i 9. siječnja 2009. u Zagrebu, ur. Tomislav Jonjić i Zlatko Matijević (Zagreb: Zajednica udruga hrvatskih vojnih invalida Domovinskog rata Grada Zagreba, 2009), str. 178-180; Vlado Oreški i Milan Nikolić, Sibirski pečat (Zagreb: Sveučilišna naklada Liber, 1983), str. 59-61; Zigmund Kraus, "Iz Jugoslovenskih Glavnjača: Jezoviti prikaz mučenja S. Krausa," u Stara Jugoslavija i komunizam: Zakoni, sudovi, zakoni i logori u staroj Jugoslaviji protiv komunista, ur. Ivan Ribar (Zagreb: Stvarnost, 1967), str. 187-190; Josip Horvat, Živjeti u Hrvatskoj 1900-1941: Zapisci iz nepovrata (Zagreb: Sveučilišna naklada Liber, 1984), str. 309-310; Dobrivojević, Državna represija u doba diktature kralja Aleksandra, str. 178-181; Ivana Dobrivojević, "Policija i žandarmerija u doba šestosiječanjskog režima kralja Aleksandra (1929. - 1935.)," Časopis za suvremenu povijest 38, br. 1 (2006): str. 112-113, 116-117. Dobrivojević piše kako je Bedeković bio pravoslavne vjere, što je točno - na pravoslavlje je prešao nakon razvoda od prve supruge Vjere Pliverić i vjenčanja sa Zorom rođ. Bačić, bivšom suprugom upravitelja zagrebačke policije s početka 20-ih godina 20. stoljeća Ljudevita Zimpermanna. Usp. Stipančević, "Vampir iz Petrinjske," str. 115-116. Nadalje, sa »sigurnošću ne može [se] tvrditi da je podrijetlom bio Hrvat«. Dobrivojević, "Policija i žandarmerija," str. 122.

17 HR-HDA-890. Zbirka personalija, br. 1258; Stipančević, "Vampir iz Petrinjske," str. 119-120. 
1932. smijenjen je s dužnosti najvjerojatnije zbog međunarodnoga pritiska generiranoga rastućim nezadovoljstvom u domaćoj javnosti. ${ }^{18}$ Time, međutim, policijsko nasilje nije prestalo. Samo ga je (možda nešto pronicljivije) nastavio provoditi dotadašnji Bedekovićev zamjenik Stanoje Mihaldžić. ${ }^{19}$ Nakon odlaska iz Zagreba, jedno je vrijeme bio upravitelj policije u Skopju ${ }^{20}$ a od 1934. i predsjednik upravnoga suda u Celju. ${ }^{21}$ Usprkos činjenici da je onodobna domaća i inozemna javnost $s$ njima bila itekako upoznata, nikada nije odgovarao za nedjela počinjena u vrijeme upravljanja zagrebačkom policijom. Preminuo je od uznapredovaloga raka gušterače u svojem gornjogradskom stanu u Matoševoj br. 4, u prijepodnevnim satima 9. travnja 1938. godine. Dva dana kasnije pokopan je u obiteljskoj grobnici na zagrebačkom Mirogoju. ${ }^{22}$ Prema predaji, još uvijek živoj među članovima njegove šire obitelji, u potpunoj tajnosti. ${ }^{23}$ Valjda zbog straha od skrnavljenja groba i moguće odmazde prema supruzi i sestrama.

Usprkos osobnosti »sadističkog terorista«, ${ }^{24}$ Bedeković je slovio i za »simpatičnu, lijepo odjevenu, dosta inteligentnu osobu odličnih manira« ${ }^{25}$ Čini se da je zaista bio neuravnotežen i sazdan od proturječnosti. Prije preuzimanja zvučnih dužnosti i potpunoga predavanja progonu protivnika Aleksandrova režima, kao izvrsni sokolski gimnastički trener, sam je ili u suradnji, objavio priručnike za sokolske trenere ${ }^{26}$ te gimnastičarke ${ }^{27} \mathrm{i}$ gimnastičare.$^{28} \mathrm{U}$ publicistici se okušao i kao pravnik potpisujući kazalo pravnih propisa od 1905. do 1925. pod naslovom

18 Usp. HR-HDA-144. SB UO, pov. br. 7402; Čapo, Kraljevina čuvara, str. 148-149, 252; Josip Horvat, Hrvatski panoptikum (Zagreb: Globus, 1982), str. 191. Iscrpnije o inozemnim novinskim izvještajima vezanim za metode zagrebačke policije usp. Dobrivojević, Državna represija, str. 180-182.

19 Usp. dopise odvjetnika Ive Politea upravitelju zagrebačke policije od 3. listopada 1932. te ministru unutrašnjih poslova Antonu Korošecu od 26. veljače 1936. u: HR-HDA-416. OP PI, kut. 51. Usp. Kisić-Kolanović, Ivo Politeo, str. 338-345. Ovdje valja napomenuti da je autorica kod dopisa od 3. listopada 1932. kao adresata krivo navela Janka Bedekovića (str. 338). Njega je u to vrijeme već zamijenio Mihaldžić, ali su policijske metode očito ostale iste.

20 HR-HDA-1561. SDS RSUP-a SRH, 010.3.7; Stipančević, "Vampir iz Petrinjske," str. 127.

21 HR-HDA-890. Zbirka personalija, br. 1258; Stipančević, "Vampir iz Petrinjske," str. 127.

22 HR-DAZG-10. Gradsko poglavarstvo Zagreb, Zdravstveni odsjek, Mrtvozornički registar za 1938. godinu, 190; Stipančević, "Vampir iz Petrinjske," str. 127.

23 Prema razgovoru autora s Ivanom Perakom, Bedekovićevim nasljednikom po liniji njegove sestre Ljubice Amalije 13. rujna 2017., u negdanjem Jankovu stanu, Matoševa br. 4.

${ }^{24}$ Horvat, Živjeti u Hrvatskoj 1900-1941, str. 310.

25 Ivan Očak, Krleža - Partija: Miroslav Krleža u radničkom i komunističkom pokretu 1917-1941 (Zagreb: Spektar, 1982), str. 178.

${ }^{26}$ Janko Bedeković, Neiscrpiva građa za pripravu sokolskih prednjaka (Sušak: Tehnički odbor Župe Rijeka, 1922).

27 Janko Bedeković i Dragutin Šulce, Vježbe na konju za učenice, naraštajke i sokolice (Zagreb: Vlastita naklada, 1923).

28 Janko Bedeković i Dragutin Šulce, Vježbe na konju za đake, naraštaj i sokolove (Zagreb: Vlastita naklada, 1923). 
Zbirka zakona, naredaba $i$ svih propisa državne uprave po abecednom i vremenskom redu (Zagreb: Vlastiti naklada, 1926).

Možda ponajbolji opis "vampira iz Petrinjske« ostavio je njegov suvremenik i nenadmašni kroničar onodobne hrvatske društvene zbilje, novinar i publicist Josip Horvat. Zbog uvjerljivosti iščitavanja njegova fizičkoga izgleda i osobnosti na ovom ga mjestu nije na odmet prenijeti u cijelosti kako bi se što zornije prikazale proturječnosti Bedekovićeve prirode.

"Janku Bedekoviću uzaludno je tražiti uzor među istaknutima policijskim ljudima. Nije bio Fouché. ${ }^{29}$ Strana mu bijaše svaka ideja, osjećaj, neka odanost, nazor na svijet. Bio je profesionalni policajac jamačno zato jer je policija bila zacijelo jedino područje gdje je mogao iživjeti donekle svoje psihopatske sklonosti. Potomak baroknoga plemstva Hrvatskog zagorja, ${ }^{30}$ nosio je u svojoj vanjštini biljege dekadentne rase, no na prvi pogled ni u koga ne bi pobudio sumnju o svojim sklonostima. Sitan, no proporcionalno građen, s licem koje je možda u nijansama asimetrije oštrih dugoljastih crta odavalo neuravnoteženost. Samo su mu oči bile čudne: sitne, nemirne kao u vjeverice. U lovačkom odijelu ili u fraku teško bi bilo u njemu naslutiti rafiniranog krvnika - bijaše tip zagorskog vlastelina, ili bivšeg austrijskog kavalerijskog oficira. Osobno je bio, kazivahu oni koji su s njim dolazili zajedno u društvo, vrlo ugodan, udvoran, ljubezan i duhovit, u muškom je društtvu bio moćan potator ${ }^{31}$ I bio je poznat kao sakupljač bidermajerskog pokućstva. Dapače stručnjak na tom području. Katkad bi se s društvenih priredbi znao oko ponoći izgubiti, vrativši se tek oko druge ure. Žene kojima je cjelivao ruke, jamačno nisu ni slutile da je kroz ta dva sata vlastoručno mučio svoje uhapšenike na policiji, tukao ih do krvi, zabijao im čavle pod nokte, između dva turnusa bičevanja silovao koju uhapšenicu, zatim se umio, izmolio po koju molitvu klečeći pred propelom i - vratio na zabavu. ${ }^{32}$

\section{Predstava za javnost}

Kao i o njezinu najvjerojatnijem idejnom začetniku, svojevremenom nalogodavcu i financijeru Bedekoviću i o Mladoj Jugoslaviji vrlo se je malo zna(lo). Također, kao i u njegovu slučaju, ono malo dosad objavljenih podataka

\footnotetext{
29 Horvat na ovome mjestu misli na Josepha Fouchéa (1759.-1820.), francuskoga svećenika, policajca i političara poznatoga po mijenama političkih uvjerenja, koji je, među ostalim, za vrijeme upravljanja ministarstvima policije i unutarnjih poslova izgradio sveobuhvatnu policijsku organizaciju te agentsku i doušničku mrežu priječeći otpore Napoleonovu režimu. Dalibor Brozović, Hrvatska enciklopedija: 3: $D a-F o$ (Zagreb: Leksikografski zavod Miroslav Krleža, 2001), s. v. Fouché, Joseph.

30 Autor je tu kao i Krleža griješio oko Bedekovićeva podrijetla. Usp. Vlaho Bogišić, Marginalije o gradovima i ljudima (Zagreb: Naklada Ljevak, 2016), str. 84. Kao što smo ranije vidjeli, Janko je rođen kao potomak turopoljskih Bedekovića Kobilićkih, a ne poznatijega zagorskog roda Bedekovića Komorskih.

31 Konzument alkohola, pijanac.

32 Horvat, Živjeti u Hrvatskoj, str. 309.
} 


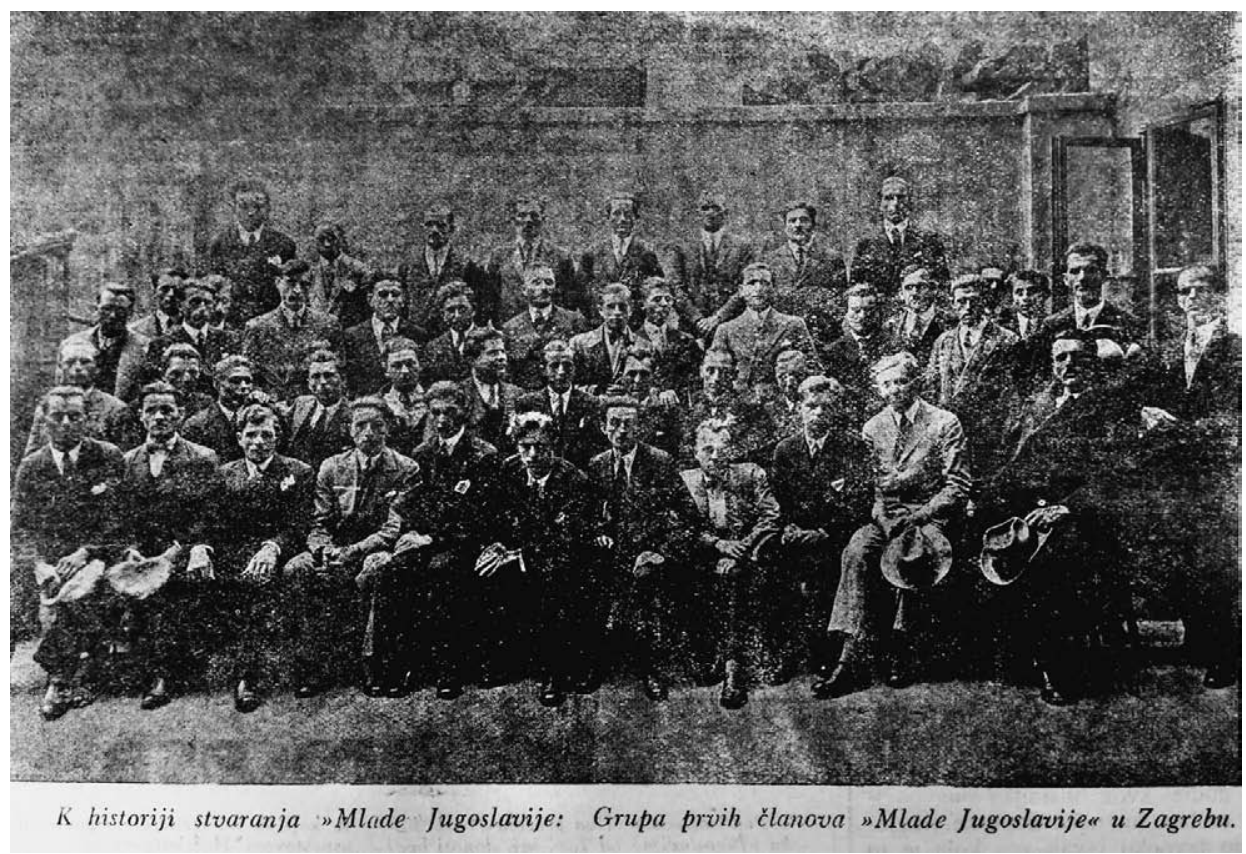

Slika 2. Rijetka sačuvana slika pripadnika Mlade Jugoslavije. Mlada Jugoslavija, br. 5 (16. svibnja 1931): str. 5.

vezanih za to društvo u historiografskoj je literaturi oskudno, nejasno ili nedovoljno precizno. Počevši od samoga naziva preko ukupne ideologije, članstva, rasprostranjenosti pa do metoda rada i ciljeva. ${ }^{33}$ Spomenuto nimalo ne čudi jer je udruženje, čini se, imalo dva posve različita lica. Jedno službeno, "zakonito" i arhivskim vrelima ponajviše potkrijepljeno, nasuprot batinaškomu, terorističkomu i gotovo nepoznatomu, sačuvanomu u sjećanjima zagrebačkih intelektualaca, neposrednih sudionika onodobnih društvenih zbivanja i u ponekom dokumentu koji ih potvrđuje.

Iako se u razlozima osnivanja Mlade Jugoslavije provlačila ideja praktične i institucionalne potpore vladareve odluke o nametanju diktature početkom

33 Usp. Horvat, Hrvatski panoptikum, str. 250-251; Janjatović, Politički teror u Hrvatskoj 1918.-1935., str. 302-303. Na ovom mjestu valja naglasiti da je autorica u kontekstu suđenja za ubojstvo Milana Šufflaya u navedenom djelu spominjala pripadnike Jugoslavenske akademske čitaonice, koji su, tobože, djelovali pod pokroviteljstvom zagrebačke policije (str. 303). Čini se da su i onodobna tijela vlasti, što namjerno što slučajno, brkala Jugoslavensku akademsku čitaonicu i Mladu Jugoslaviju. Usp. izvještaje o napadu paklenim strojem na sjedište Mlade Jugoslavije (HR-HDA-144. SB UO, pov. II. br. 2005/1931) te dokumente o sudskom postupku protiv sudionika atentata na Šufflaya (HR-HDA-397. DN, kns 41/1932). O pravilima Jugoslavenske akademske čitaonice usp. HR-HDA-1353. Grupa VI, inv. br. 3973/1, 4097. 
siječnja 1929. te proglašenju zakona o promjeni administrativnoga ustroja i imena države nepunih deset mjeseci kasnije, ${ }^{34}$ osnivačka skupština društva održana je (tek) 2. svibnja 1930. u prostorijama zagrebačke Narodne restauracije pod predsjedanjem Ivana Brkića, osobe osebujnoga karaktera o kojoj je više riječi nešto kasnije. Na skupštini je od 65 prijavljenih sudjelovalo četrdesetak simpatizera, a na događaju je kao posebni izaslanik upravitelja zagrebačke policije bio agent političkoga odsjeka Janko Pukmajster. ${ }^{35}$

U hvalospjevnom Brkićevu uvodnom govoru o Petru i Aleksandru Karađorđeviću, oslobođenju i jedinstvu Srba, Hrvata i Slovenaca, vladarevoj "mudroj gesti« od 6. siječnja 1929. te »neumornom narodnom radniku« Petru Zivkoviću, naznačeni su i temelji iz kojih je trebala izniknuti nova društvena organizacija. Većina njezinih inicijalnih članova, prema Brkićevim je riječima, prije uvođenja diktature pripadala pomlatku HSS-a, a u novo se udruženje s posve različitim ideološkim predznakom uključila kako bi kralju, zauzetomu uređenjem i upravljanjem državom, pružala potporu u radu za dobrobit društva te kako bi njezini članovi "ugušili svoje neprijatelje i svom silom savladali svaki onaj pokušaj, koji bi vodio da učini među nama razdor i neslogu« ${ }^{36}$ Samo je i tih nekoliko posljednjih riječi dovoljno da se nasluti što je uistinu stajalo iza organiziranja Mlade Jugoslavije i kakvim se je metodama njezino članstvo planiralo služiti u izgradnji nacionalnoga jedinstva i blagostanja građana jugoslavenske države. Nije na odmet primijetiti da su se već u prvim trenutcima neizravno dali prepoznati i nalogodavci. Policija je, naime, otpočetka bila neprikriveno uključena u organizaciju društva, a osnivačka se skupština, ako je točna pretpostavka da su Narodna restauracija i Narodna kavana u Đorđićevoj istovjetni lokali, održala u neposrednoj blizini Bedekovićeva redarstvenoga gnijezda u Petrinjskoj. Sljedeći događaji i o njima sačuvani arhivski dokumenti skopčani sa sjećanjima suvremenika te pretpostavke dodatno potvrđuju.

Da je osnivanje društva bilo unaprijed dobro pripremljeno, govori podatak da je nacrt pravila i prije skupštine bio usuglašen te da su ona usvojena jednoglasno, kao što je uostalom jednoglasno izabran i Upravni odbor, koji su osim "vođe bivše matice seljačke stranke" Brkića kao predsjednika činili podpredsjednici, »dekorativni slikar" Davorin Vinković i privatni namještenik Milan Smetko, tajnici činovnik Josip Tomljanović i student Ivan Cvetković te blagajnici građevinar Slavko Đurak i student prava Stanko Špoljer. Jednoglasno je izglasano i sedam odbornika upravnoga te četiri člana nadzornoga odbora. Istodobno sa spomenutim, na osnivačkoj je skupštini iskazana i potreba za pokretanjem glasila društva, u obliku dnevnih novina kroz koje su se ideje jugoslavenske nacionalne omladine

\footnotetext{
34 “Omladina ima riječ!" Mlada Jugoslavija 1, br. 1 (4. travnja 1931.): str. 1.

35 HR-HDA-1353. Grupa VI, inv. br. 2917. Ponešto o Pukmajsteru usp. HR-HDA-1561. SDS RSUP-a SRH, 010.3.7.

36 HR-HDA-1353. Grupa VI, inv. br. 2917.
} 
trebale proširiti u široj zajednici. ${ }^{37}$ I samo pomišljanje na pokretanje takve publikacije prije nego što se je društvo uopće osovilo na noge moralo je značiti da je čelništvo znalo da su izvori financiranja udruženja obilati, a logistička potpora njezinu radu zagarantirana.

Pravila društva od Odjeljenja za državnu zaštitu Ministarstva unutrašnjih poslova potvrđena su sredinom lipnja 1930., a doskora su i tiskana u jednoj zagrebačkoj tiskari. ${ }^{38}$ Kao članovi osnivačkoga odbora u njima su navedeni već ranije spominjani Brkić, Đurak, Smetko, Tomljanović te Zvonimir Topolnik. Društvo je prema tim pravilima osnovano sa »svrhom širenja, jačanja i razvijanja svih nacionalnih, prosvjetnih, ekonomskih, te socijalnih sposobnosti i vrlina, [...] te razvijanja i jačanja smisla kako za opću Jugoslavensku državnu misao tako i za javnu solidarnost sviju Jugoslavena, tako i pobijanje nepismenosti i alkoholizma«. Spomenuto se naumilo činiti održavanjem obrazovnih tečajeva, predavanja i sastanaka, osnivanjem knjižnica te širenjem "dobrih" knjiga, zabavnih i stručnih časopisa i novina. Financiranje društva na sebe je, barem na papiru, preuzimalo samo članstvo putem članarina, prinosa i dobrovoljnih darova te "kamatama od korisno uložene društvene imovine«. Redoviti su članovi prilikom pristupa društvu plaćali 5 dinara, isto koliko su morali davati i za mjesečnu članarinu, a članovi utemeljitelji godišnje su bili obvezni uplatiti svotu od najmanje 500 dinara. $^{39}$

Upravu društva činili su upravni i nadzorni odbor te glavna skupština. Upravni je odbor upravljao društvom i raspolagao imovinom, sazivao sjednice glavne skupštine, podnosio tajničke i blagajničke izvještaje, provodio odluke glavne skupštine, primao, brisao i isključivao članove. Za donošenje pravovaljanih odluka morao je zasjedati s najmanje dvije trećine prisutnih članova. Odluke su se izglasavale običnom većinom, a u slučaju jednakoga broja presudnim se držao stav predsjedatelja. Također, jedna od važnih zadaća upravnoga odbora bilo je osnivanje podružnica na teritoriju čitave Kraljevine. ${ }^{40}$ Predsjednik društva imao je prilično široke ovlasti. Predstavljao je i zastupao društvo pred vlastima i trećim osobama, sazivao i predsjedavao sjednicama upravnoga odbora i glavne skupštine, vodio brigu o provođenju svih društvenih djelatnosti, s tajnikom potpisivao svu dokumentaciju upravnoga, a s blagajnikom financijskoga karaktera. ${ }^{41}$

Središnja ideološka platforma koju je propagiralo udruženje bila je jednostavna: "stvaranje velike, jedinstvene i snažne Jugoslavije u kojoj će zadovoljno živjeti veliki, jedinstveni i snažni jugoslavenski narod». Shodno tomu, glavni

37 HR-HDA-1353. Grupa VI, inv. br. 2917.

38 Pravila Omladinskog društva "Mlada Jugoslavija" (Zagreb: Tiskara Merkantile, 1930).

39 Pravila Omladinskog drustva, str. 3-4.

40 Pravila Omladinskog društva, str. 8-9.

${ }^{41}$ Pravila Omladinskog društva, str. 15. 
zadatak članstva odnosio se na generiranje pravilnih stavova i mnijenja o društvenim i političkim zbivanjima, ponajprije putem neposredne edukacije i modernoga tiska kojim se mladeži valjalo ukazati na vrijednosti jugoslavenskoga jedinstva, mijenjajući krive ili učvršćujući ispravne stavove pojedinaca i skupina. ${ }^{42}$ Širenje (jugoslavenskoga) nacionalizma kroz, napose, instituciju moderne tiskovine dakako nije bila nova, ali ni nazadna ideja. Posve je jasno da se opismenjavanjem širih društvenih slojeva produbljivao i utjecaj tiska na stvaranje općih stavova prema svim sastavnicama društva i vlasti. To su u Mladoj Jugoslaviji dobro znali. Drugim riječima, znao je to Brkić, jer nema prevelike sumnje da je pod njegovim ravnanjem službeno glasilo na zavidnoj razini izlazilo gotovo pet godina, sve dok izvori financiranja nisu presahnuli i dok u Kraljevini nisu počeli puhati drukčiji politički vjetrovi. Malo je sumnje, također, da je tiskanje i raspačavanje glasila pored osnivanja podružnica na terenu bio i jedini ispunjeni (formalni) cilj Mlade Jugoslavije. Drugi, zbog kojih je osnovana, postizani su na drukčije načine.

Glasilo društva započelo je s izlaženjem 4. travnja 1931. godine. Sjedište uredništva i uprave lista, kao i čitavoga udruženja, nalazilo se u Ulici Kraljice Marije br. 36 (današnja Hebrangova). ${ }^{43}$ Pretplata na Mladu Jugoslaviju iznosila je 50 dinara godišnje za domaće te 100 dinara za inozemne pretplatnike. List je trebao izlaziti jednom tjedno, u pravilu petkom ${ }^{44}$ u nakladi od oko 4.000 primjeraka. ${ }^{45}$ Kao što je već ranije spomenuto, bila je to ozbiljna tiskovina solidne sadržajne strukture, grafičke pripreme i tiska. Od osnutka do gašenja list je uređivao Brkić, što je bilo vidljivo po kvaliteti i sadržaju tekstova, od kojih su u svim brojevima bili zastupljeni ideološki i programski prilozi članova, izvještaji o događajima vezanima za društvo od središnjice do podružnica te analize političkih događaja u zemlji i inozemstvu. Ne treba posebno naglašavati da su svi članci pisani iz perspektive radikalnoga jugoslavenskog nacionalizma i da se list, prije svega, obraćao mlađoj publici, zbog čega su prilozi često odisali pretjeranim političkim i društvenim poukama. Negativni su stavovi, dakako, bili upereni prema najopasnijim protivnicima režima - pripadnicima ustaškoga i komunističkoga pokreta.

Za čitavoga razdoblja izlaženja Mlada Jugoslavija tiskana je u zagrebačkoj štampariji Merkantile, kojoj je (su)vlasnik bio Zagrepčanin Đuro Jutriša, inače do 1929. član Hrvatske federalističke seljačke stranke nastale spajanjem članstva

\footnotetext{
42 HR-HDA-1353. Grupa VI, inv. br. 2917.

43 Kuća u čijem se prizemlju smjestilo sjedište Mlade Jugoslavije nalazila se (i još se uvijek nalazi) na uglu Ulice Kraljice Marije (danas Hebrangova) i Gundulićeve. U kontekstu povezanosti Mlade Jugoslavije i struktura onodobnih zagrebačkih vlasti nije nevažno spomenuti da su se na prvom katu susjedne kuće (br. 34) tada nalazili prostori Političkoga odsjeka gradskoga načelništva. Usp. HR-HDA-144. SB UO, pov. II. br. 2005/1931.

44 Usp. Mlada Jugoslavija 1, br. 1 (4. travnja 1931.): str. 1.

45 HDA-1361. Grupa XVIII, inv. br. 947.
} 
Hrvatske zajednice i prebjega iz redova HSS-a. Jutriša se ni prije ni nakon uvođenja diktature nije pretjerano isticao političkim djelovanjem. ${ }^{46}$ Čini se da je bio jedan od brojnih "podupiratelja" rada Brkićeva društva koji je, kao i drugi onodobni zagrebački imućnici, davanjem priloga u novcu ili uslugama legitimirao odanost kralju i državi dobivajući pritom nekakvo osobno osiguranje od mogućih napada Bedekovićevih agenata, konfidenata i "tulumaša". ${ }^{47}$

Kao istaknuti suradnik Mlade Jugoslavije uz urednika Brkića zabilježen je Jeronim Jerko Čogelja iz Konjevrata nedaleko Šibenika, do uvođenja diktature viđeniji član mladeži HSS-a i urednik Hrvatskoga glasa, oporbene tiskovine koja je od 1926. do 1927. izlazila u Brodu na Savi. ${ }^{48}$ Cogelja je u ožujku 1929. bio uhićen zbog sumnje na umorstvo novinara i kraljeva navodnoga miljenika Tonija Schlegela, ali je odlukom suda oslobođen optužbi. ${ }^{49}$ Vrlo vjerojatno je tada, zastrašen Bedekovićevim prijetnjama, pristao na promjenu političkoga kaputa. Čini se da je na taj način za suradnju pridobiven i Duvnjak Ive Nevistić, također osoba s policijskim dosjeom iz 1923. pod optužbom za protudržavno djelovanje te za silovanje godinu kasnije. Viđeniji suradnik lista bio je i raniji haesesovski omladinac, student visoke komercijalne škole, Istranin Srećko Dobrila. ${ }^{50}$

Društvo je i prije nego li je pokrenulo vlastito glasilo, s promjenjivim uspjehom započelo širenje mreže podružnica na mjesta u provinciji. Uostalom, i službeni i prikriveni zadatci od početka nisu bili vezani isključivo za Zagreb i okolicu, a s ograničenim djelokrugom nisu se zadovoljavali ni čelnici udruženja ni "gospodari lutaka" i financijeri iz sjene. Raspoloženje naroda, s druge je strane, bilo prilično kolebljivo. Čini se da je osnivanje podružnica najbrže prolazilo u neposrednoj blizini metropole, gdje je jeka Bedekovićeva terora i zov njegovih povlastica bio dovoljno snažan da negdanje haesesovce nagna na ideološki zaokret. Zasigurno su u tom veliku ulogu imala i osobna poznanstva članova iz središnjice i onih s terena. Tako je početkom 1931. zabilježeno osnivanje podružnica Mlade Jugoslavije u Orleu i Veleševcu u Turopolju, Sesvetama, Markuševcu, Čučerju, Zaprešiću, Remetama i Sesvetskom Kraljevcu. ${ }^{51}$ Međutim, produžena ruka zagrebačke policije našla je poklonike i u Varaždinu, Maloj Erpenji kod

\footnotetext{
46 HDA-1361. Grupa XVIII, inv. br. 947.

47 Horvat, Hrvatski panoptikum, str. 250.

48 Dunja Kokanović, "Izašao novi lokalni list u Brodu," Brodportal (31. prosinca 2016), pristupljeno 27. ožujka 2019., http://www.brodportal.hr/clanak/izasao-novi-lokalni-list-u-brodu-14542.

49 HDA-1361. Grupa XVIII, inv. br. 947. O atentatu na Schlegela usp. Bogdan Krizman, Ante Pavelic i ustaše (Zagreb: Globus, 1978), str. 69; Tomislav Jonjić, "Proces Hranilović-Soldin: Prilog poznavanju postanka ustaškog pokreta," u Hrvatska između slobode i jugoslavenstva: Zbornik radova sa znanstvenog skupa održanog 8. i 9. siječnja 2009. u Zagrebu, ur. Tomislav Jonjić i Zlatko Matijević (Zagreb: Zajednica udruga hrvatskih vojnih invalida Domovinskog rata Grada Zagreba, 2009), str. 167-196.

50 HDA-1361. Grupa XVIII, inv. br. 947.

51 HR-HDA-1354. Grupa VII, inv. br. 971.
} 
Tuheljskih Toplica, Sv. Križu Začretje, Petrovskom (nedaleko Krapine), Oštarijama kod Ogulina, Virovitici, ${ }^{52}$ Bobovcu kod Sunje. ${ }^{53}$

Podrijetlom je članstvo uz rijetke iznimke gotovo u potpunosti spadalo u hrvatski etnički korpus, a broj članova u podružnicama obično se kretao između dvadeset i sedamdeset, izuzev središnjice, koja je bila najbrojnija. Ako je vjerovati podatcima koji su dolazili iz samoga društva, ukupan broj članova Mlade Jugoslavije potkraj 1935. prelazio je tri tisuće. ${ }^{54}$

Svemu unatoč, dosezi u organiziranju podružnica bili su ograničeni, a čini se da ni društvo u cjelini nije funkcioniralo onako kako su to željeli poslodavci. Zaposlenici banske uprave 1935. žalili su se Odelenju za zaštitu države pri MUP-u u Beogradu da usprkos njihovu i zalaganju zagrebačke policije željeni ciljevi nisu ispunjeni ponajprije zbog letargije i neorganiziranosti članstva, što su pripisivali samomu predsjedniku Brkiću. Druga se zamjerka odnosila na činjenicu da su u društvo primani bivši osuđenici, nasilnici, uopće osobe s kriminalnom prošlošću ili vrlo dvojbenoga morala, koje su zatim pripadnost društvu koristili kao pokriće za vlastite mutne poslove. ${ }^{55}$

Kakogod bilo, Brkić je, ili pod prisilom ili sam shvativši da udruženje slabo djeluje, odlučio pokušati reformirati svoje čedo i spasiti što se dalo. Početkom 1935. na konferenciji članstva poduzete su mjere za reorganizaciju središnjice. I na tom je sastanku bio posebni izaslanik zagrebačke policije. Iako Bedekovića već dugo nije bilo, njegov je nasljednik Mihaldžić nastavljao utrtim putem. $\mathrm{Na}$ predsjednikov prijedlog prihvaćeno je sazivanje skupštine zagrebačke središsnjice za kraj veljače, a za tu je prigodu izabran i privremeni odbor u kojem više nije bilo ni jednoga člana s početka organiziranja društva pet godina ranije. Osim Brkića. Novi zamah društvu nastojao se dati organizacijom odlaska poslanstva Mlade Jugoslavije na Aleksandrov grob u Oplencu, primanjem žena (što dotad nije bio slučaj), pojačanim nadzorom nad ćudoređem među članstvom, organizacijom zabavnih programa radi prezentiranja društva u novom svjetlu te humanitarnim i javno korisnim radom. Posebno se je, također, trebalo pozabaviti brisanjem antihrvatske stigme, koja je društvo pratila u javnosti prije svega isticanjem nacionalnoga jugoslavenskog jedinstva, ali ne putem negiranja narodnih posebnosti. ${ }^{56}$

\footnotetext{
52 HR-HDA-1354. Grupa VII, inv. br. 971.

53 HR-HDA-1359. Grupa XVI, inv. br. 722. Ovdje treba pripomenuti da su na I. kongresu društva u rujnu iste godine spomenute i sljedeće ispostave: Biškupec, Cabuna, Dvor na Uni, Duga Resa, Graberje, Crni Lug, Pregrada, Pretkovec, Sv. Ivan Zelina, Vinkovci, Oborovo, Zabok, Zrin, Novigrad, Vrapče, Donja Dubrava, Špišić Bukovica, Stenjevec, Mrzla Vodica, Fužine, Virje i Beograd, što svjedoči o priličnoj društvenoj aktivnosti članstva na terenu. HR-HDA-145. SB ODZ, str. pov. 3005/1932.

54 HR-HDA-1354. Grupa VII, inv. br. 971; HR-HDA-145. SB ODZ, str. pov. 3005/1932.

55 HR-HDA-145. SB ODZ, str. pov. 14/1935.

56 HR-HDA-145. SB ODZ, str. pov. 14/1935.
} 
Nije to bio prvi pokušaj da se društvo organizacijski učvrsti. Naime, jedva nešto više od godinu dana od donošenja prvih pravila, u rujnu 1931. organiziran je I. izvanredni kongres, na kojem je usvojen dokument pod nazivom Ideologija $i$ program Mlade Jugoslavije s pravilima. U njemu su se, osim podcrtavanja zadataka članstva u radu na nacionalnom jedinstvu te neupitne i bezrezervne odanosti kralju i beogradskim vlastodršcima, mijenjala postojeća pravila. Jedan dio promjena bio je kozmetičke prirode u vezi s primanjem članova i njihovim dužnostima, a znatniji je zahvat učinjen u samoj strukturi društva, valjda zbog širenja rada na podružnice. Tada je kao glavno upravno tijelo uspostavljeno vrhovno vijeće, a preostala su činili upravni i nadzorni odbor mjesnih organizacija te glavna skupština mjesnih organizacija. Dakako, sva je upravna vlast u društtvu bila koncentrirana u (od Kongresa biranom) vrhovnom vijeću, odnosno u rukama njezina predsjednika. ${ }^{57} \mathrm{Na}$ I. izvanrednom kongresu društva bilo je prisutno 106 delegata iz 38 podružnica te zagrebačke središnjice. Donekle je zanimljivo da je beogradska ispostava Mlade Jugoslavije na kongres uputila devetočlano poslanstvo, a to je i jedini pronađeni podatak koji svjedoči o organizaciji podružnice društva izvan okvira Hrvatske..$^{58}$ Gotovo i ne treba sumnjati da je taj događaj predstavljao zenit Mlade Jugoslavije, kao što je to doba predstavljalo i vrhunac Bedekovićeva društvenoga utjecaja i policijskoga nasilja.

\section{Fantom Ivan Brkić i njegovi jataci}

Brkić je rođen u Zrinu nedaleko Dvora (na Uni) 1902. u obitelji Petra i Ane rođene Maraković. ${ }^{59}$ Kao što je ranije spomenuto, bio je istaknuti član HSS-ove mladeži. Vjerojatno do 1929. i drugoga Bedekovićeva dolaska na čelo zagrebačke policije, ${ }^{60}$ a možda je policijskim konfidentom bio još od 1925. godine. Potonje se godine izvjesni Ivan Brkić spominje i kao urednik osječkoga oporbenoga Hrvatskoga lista. ${ }^{61}$ Vrlo je vjerojatno riječ o istoj osobi, iako je spomenuto zasad nemoguće nedvojbeno utvrditi. Opravdanost takve pretpostavke daje naslutiti i činjenica da je u to vrijeme Hrvatski list kao glasilo Hrvatske zajednice još uvijek bio sklon HSS-ovoj republikanskoj politici, s kojom je raskrstio po

\footnotetext{
57 Za predsjednika vrhovnoga vijeća tada je izabran Brkić, a ostali su članovi bili Slavko Đurak (Zagreb), Paja Šumanovac (Vinkovci), Boža Martinović (Beograd), Mladen Engelsfeld (Veleševac), Josip Martinko (Zagreb), ? Kuzmanović (Ogulin), Viktor Centić (Lokve), Aladar Weiss (Varaždin), Vilko Žiljak (Sv. Ivan Zelina), Andrija Stosić (Feričanci), Vid Đuretak (Vrapče), Josip Mihalić (Duga Resa), Ivan Ferega (Virovitica) i Mijo Krivošić (Zrinj). HR-HDA-145. SB ODZ, str. pov. 3005/1932. O osnivanju podružnice u Varaždinu usp. HR-HDA-145. SB ODZ, pov. II. 292/1931. O osnivanju podružnica u Stenjevcu i Vrapču usp. HR-HDA-144. SB UO, pov. br. 15330.

58 HR-HDA-145. SB ODZ, str. pov. 3005/1932.

59 HR-HDA-1361. Grupa XVIII, inv. br. 947.

60 HR-HDA-1361. Grupa XVIII, inv. br. 947.

${ }^{61}$ Od br. 46 (7. ožujka 1925.) do br. 65 (29. ožujka 1925).
} 
Radićevu izlasku iz zatvora. Također, još je jedan podatak koji tomu govori u prilog to da osoba imena Ivan Brkić nikada nije bila zavičajna u Osijeku. ${ }^{62} \mathrm{O}$ mogućnosti da su u tadašnjem hrvatskom novinarskom miljeu postojale dvije osobe istoga imena i da su bile sposobne proizvesti ozbiljan izdavački proizvod poput dnevnih novina, ne treba ni govoriti. Uostalom, sličnu sudbinu urednika oporbenoga lista a kasnije suradnika Mlade Jugoslavije dijelio je i Brkićev suradnik Čogelja.

Krajnji će odgovori, međutim, i dalje ostati nepotpuni. Dokumentacija uredništva spomenutoga lista gotovo da i nije sačuvana, ${ }^{63}$ a sam dnevnik, nažalost, nije donio podrobnije informacije o osobi koja je nakratko zamijenila glavnoga urednika. Je li doista bila riječ samo o unaprijed planiranoj zamjeni za vrijeme "dopusta" dugogodišnjega urednika Josipa Pavišića, kako se to tvrdilo nakon što je Brkić napustio uredništvo, ${ }^{64}$ nije posve sigurno. Postavlja se pitanje zbog čega bi se u vrijeme kratkotrajna izbivanja najvažnije osobe lista odjednom kao urednik pojavila sasvim nova? U izdavačkoj praksi nije poznato da su se urednici odricali potpisivanja publikacija za vrijeme trajanja odmora, a to se više nikada nije ponovilo ni u Pavišićevu inače dugogodišnjem mandatu uređivanja Hrvatskoga lista. Možda se u presedanu Brkićeva dolaska na mjesto glavnoga urednika jednoga od najutjecajnijih slavonskih oporbenih listova krio pokušaj snaženja krhkih odnosa haesesovaca i zajedničara, a možda je već u to vrijeme Brkić bio na listi Bedekovićevih plaćenika te je kao takav određen za unošenje dodatnoga razdora među protivnike režima i špijuniranje u korist zagrebačke policije. "Ruku na srce", dvadesetak brojeva koje je potpisao ne potvrđuju potonje mišljenje, jer su neznatno izmijenjeni u odnosu na one koje je uređivao Pavišić. I izgledom i sadržajem. U konačnici, možda je Brkićev angažman u osječkom glasilu bila samo jedna od njegovih brojnih i kratkotrajnih životnih stranputica, dug onoliko koliko je trajalo i povjerenje u nj kao sposobnu, ozbiljnu i čestitu osobu.

Ipak, nije posve nemoguće da je Brkić bio policijskim čovjekom još prije nego li je i formalno napustio HSS nakon uvođenja diktature. Ne bi bio ni prvi ni posljednji kojega je Bedeković uspio tako vrbovati. Uostalom, u nažalost nepotpisanom i nedatiranom izvještaju o stanju u Mladoj Jugoslaviji, vjerojatno nastalom na traženje Banske uprave Savske banovine 1931., nedvosmisleno je navedeno da je inicijativa za osnivanje udruženja pristigla "odozgora" te da je Brkić za ulogu okupljanja omladine iz različitih političkih partija u jednu organizaciju koja je trebala raditi »u duhu Kraljevih intencija» izabran jer se je smatralo da će se oko njega okupiti većina, ne samo haesesovske, hrvatske omladine. Zauz-

\footnotetext{
62 Stjepan Sršan i Vilim Matić, Zavičajnici grada Osijeka 1901.-1946. (Osijek: Državni arhiv u Osijeku, 2003). Predsjednik Mlade Jugoslavije i kasniji urednik istoimenoga lista bio je zavičajan u Zrinu. HR-HDA-1361. Grupa XVIII, inv. br. 947.

${ }^{63}$ Usp. HR-DAOS-1429. Građanska tiskara Osijek.

64 “Gradske vijesti: Iz uredništva.” Hrvatski list, br. 66 (30. ožujka 1925).
} 
vrat mu je obećana novčana i druga potpora. $U$ to je vrijeme Brkić bio "policijski šikaniran « i bez namještenja, pa ne čudi da je na ponudu pristao. ${ }^{65}$ Takav razvoj događaja daje naslutiti i njegovo spominjanje u sinekurnim zvanjima dnevničara gradske blagajne u Bjelovaru 1927. ${ }^{66}$ namještenika Oblasnoga odbora Zagrebačke oblasti za porezni nadzor (trošarinâ na alkoholna pića) početkom 1928., a zatim i imenovanje "kontraktualnim ${ }^{67}$ činovnikom " Kr. banske uprave Savske Banovine u srpnju 1930. godine. Iz te perspektive, doduše, početkom 1928., dogodila se teško objašnjiva epizoda kada je uhićen i interniran u rodni Zrin zbog sumnji na pomaganje u atentatu na novinara Schlegela. ${ }^{68}$ Iako su optužbe kasnije povučene i Brkić pušten na slobodu, ne može se ne zapitati je li ipak (zajedno $s$ ranije spominjanim Čogeljom) odigrao kakvu rolu u tom događaju. Možda i po izravnom Bedekovićevu nalogu.

Na poziciji činovnika Savske banovine zadržao do početka lipnja 1932., kada je po izričitoj naredbi bana Ive Perovića otpušten iz službe. Na isto se mjesto, očito koristeći Perovićev odlazak u tročlano namjesništvo maloljetnoga kneza Pavla, pokušao vratiti u travnju 1935., ali mu je zamolba, čini se, ostala neudovoljena. ${ }^{69}$ Malo je sumnje da se iza tih formalnih namještenja skrivala dodatna i "zakonita" naknada za Brkićev rad u zaštiti režima. Državna je zavjetrina s jedne strane bila dobra krinka za obavljanje nezgodnih poslova, a s druge mogućnost dodatnoga podebljanja lisnice. Najveći dio sredstava ionako je dolazio izravno od Bedekovića, kako je to, među ostalima, kasnije tvrdio i Juraj Špiler, svojedobno Bedekovićev bliski suradnik u redovima zagrebačkoga redarstva. Prema tim je tvrdnjama Brkić za drugoga Bedekovićeva mandata često navraćao u Petrinjsku kako bi od upravitelja policije primio "subvencije vlade" za Mladu Jugoslaviju. Bili su to mjesečni iznosi od po nekoliko tisuća dinara. ${ }^{70}$

Iz spomenutoga se daju naslutiti i razlozi zbog kojih je Brkića slijedilo pedesetak njegovih drugova iz bivše haesesove omladine. ${ }^{71}$ Kao i njihov stari/novi predsjednik, osim izbjegavanja policijskoga terora, nadali su se i da će im "Beograd širom otvoriti vrata i davati velike novčane subvencije«. To je, s druge strane, ideološki "iskrenu" jugoslavensku mladež odbijalo od toga udruženja te je držanje uprave držala čistim najamništvom, što je sve skupa rezultiralo činjenicom da je i u širim slojevima stanovništva Mlada Jugoslavija smatrana plaćenom "policijskom ekspoziturom ${ }^{72}{ }^{72}$

65 HDA-1354. Grupa VII, inv. br. 972.

66 HR-HDA-145. SB ODZ, pov. br. 22007/1932.

67 Ugovornim, na određeno vrijeme.

68 HR-HDA-1359. Grupa XVI, inv. br. 480.

69 HR-HDA-890. Zbirka personalija, br. 23704.

70 HR-HDA-1561. SDS RSUP-a SRH, 010.3.7.

71 HR-HDA-1353. Grupa VI, inv. br. 2917.

72 HR-HDA-1354. Grupa VII, inv. br. 972. 
Spočetka je Brkićevo djelovanje bilo sumnjivo i beogradskim vojnim i policijskim krugovima, koji su u izvještajima o osnivanju novoga omladinskoga nacionalnog udruženja njegova predsjednika nazivali »najzatucanijim Hrvatom i Radićevcem, podstrekačem svake demonstracije protiv države«, ali istovremeno pozdravljajući promjenu ideoloških nazora osobe koja je utjerivala strah svima koji su je poznavali i od čijega su karaktera i sposobnosti novi poslodavci mogli imati samo koristi. ${ }^{73}$ Slično su o Brkiću, anonimno i očito ne bez doze straha, tvrdili i (bivši) bliski suradnici stavljajući pod znak pitanja njegove intelektualne i moralne kvalitete, držeći ga koristoljubivim, pohlepnim, rastrošnim i razmetljivim, ${ }^{74}$ a gotovo isto o njemu su tvrdili i (politički) protivnici držeći ga opskurnom osobom, hohštaplerom i teroristom. ${ }^{75}$ Iako su neke od tih kvalifikacija zasigurno bile posljedica zavisti sudrugova, ne da se oteti dojmu da se doista radilo o osobi upitna ćudoređa, kojoj su osjećaj moći i lagodan život bili važniji od politike i ideologije. Da je, međutim, pohađanje nogometnih utakmica i čitanje "šundromana " ${ }^{76}$ stavljao ispred svega ostaloga, najvjerojatnije nije posve točno. Za potvrdu tomu dovoljno je učiniti letimičan uvid u službenu tiskovinu društva koju je uređivao. Uostalom, kada je odlukom onih koji su ga na nju i postavili s društvene pozornice nestalo Brkića, nestalo je i Mlade Jugoslavije.

Doista nije pretjerano reći da su članovi Mlade Jugoslavije bili omraženi. Javnosti je bila dobro poznata njihova kriminalna, plaćenička, batinaška i iznuđivačka priroda. Brkić i njegovi ortaci to zapravo ni nisu nastojali previše skrivati. Zaštita policije i dijela državnoga aparata davala im je za pravo. Protiv toga društva glas nisu dizali samo politički protivnici, nego i onaj malen dio uvjerenih jugoslavenskih nacionalista. Možda je potonjima najamništvo pod krinkom ideologije smetalo još i više, jer su nagrade u namještenjima i novcu dobivali sasvim krivi i moralno izopačeni ljudi kojima je jugoslavenstvo bilo samo paravan za osobne probitke ili utaživanje najnižih psihofizičkih poriva.

Da su se oko društva okupljale opskurne osobe, može se razaznati već iz dosada rečenoga. Dodatno o tom svjedoče i podatci o organiziranju pojedinih podružnica Mlade Jugoslavije na terenu. Tako je ostalo zabilježeno da je čelnik virovitičkoga ogranka bio izvjesni porezni činovnik Ivan Ferega, u tamošnjem kraju poznat kao iznimno problematična osoba nadimka Virovitički Musolini. ${ }^{77}$ Njegova desna ruka bio je još mračniji i moralno sumnjiviji upravitelj pošte

\footnotetext{
73 HR-HDA-1353. Grupa VI, inv. br. 2917.

74 HR-HDA-1354. Grupa VII, inv. br. 972.

75 HR-HDA-145. SB ODZ, pov. br. 22007/1932.

76 HR-HDA-1354. Grupa VII, inv. br. 972.

77 Ferega nije bio denuncijant samo prema neistomišljenicima. Brkića je također držao protivnikom smatrajući da je »nezgodna ličnost za predsednika 'Mlade Jugoslavije' " te da dio članstva "muku muči» nastojeći ga ukloniti s položaja predsjednika vrhovnoga vijeća. HR-HDA-145. SB ODZ, pov. $2007 / 1932$.
} 
(»prevrtljiv, licemjer i hvalisavac, materijalist do skrajnosti«) Dimitrije Mita Šimić. Njih su dvojica potkraj 1931. lažima i zastrašivanjem nastojali osigurati političke i materijalne probitke tako očito da su bili privedeni u policiju i bili prisiljeni platiti novčanu globu (!) radi širenja dezinformacija. Prema onodobnim izvještajima lokalnih vlasti, virovitička je Mlada Jugoslavija bila u rukama "neozbiljnih mladića« zavedenih djelovanjem »vucibatine« i »pokvarenjaka« Šimića, što je za posljedicu imalo "profanaciju lepog imena" društva i rušenje ugleda vlade (za koju su Ferega i Šimić inače tvrdili da ih obilato podupire). ${ }^{78}$

Slično, ako ne i gore bilo je i u bjelovarskoj podružnici društva. I tamo su »aranžeri i vođe« Mlade Jugoslavije uživali »najlošiji glas« te imali »mnogo protivnika" u javnosti. Osobito se to odnosilo na predsjednika Brkića, koji je tijekom svega šestomjesečnoga boravka na mjestu zaposlenika gradske blagajne tijekom 1927. zaradio status "opskurne osobe [koju] svi mrze [...] običnog hohštaplera koji da pod okriljem idealnog društva Mlade Jugoslavije i kao navodno oduševljeni Jugoslaven vrši teror kod ispravnih i idealnih Jugoslavena «. ${ }^{79}$

Vođa bjelovarskih "mladojugoslavena” Josip Vitasović bio je od istoga soja kao i njegov predsjednik. Često policijski kažnjavani vlasnik noćne kavane, "surovog i rabiatnog ponašanja «, u narodu poznat pod nadimkom Apaš Bjelovarski. Ništa bolji nisu bili ni Vitasovićevi pomagači, podpredsjednik Milan Vukašinović, željeznički radnik, bivši podoficir nečasno otpušten iz vojne službe zbog financijskih malverzacija te tajnik Milan Konjević, bivši željezničar, otpušten zbog nesavjesnoga ponašanja i krađe te pod istragom zbog silovanja. Članovi odbora bili su također redom osobe s policijskim dosjeima - sitni kriminalci, nasilnici i prevaranti. ${ }^{80}$ Virovitica i Bjelovar nisu bile iznimke. U Ogulinu su i okolici, recimo, upravo takvi po odluci podružnice bili ovlašteni vrbovati nove članove. ${ }^{81}$

Nije začudno što su većinu članstva društva činile takve osobe: ljudi duboko poremećena morala koje je policija mogla držati u šaci i iznuđivati njihove usluge u zamjenu za materijalne probitke. Drugima, opterećenima sitnijim prekršajima, pravni ustupci i neodlazak u uze morao je značiti mnogo. Možda i

\footnotetext{
78 HR-HDA-144. SB UO, pov. II. br. 29543/1931. Koliko su bili uvjereni u vlastite obmane ili u potporu režima svjedoče i njihovi istupi u kojima su tvrdili da su upravo oni odabrani za izaslanike u narod jer kralj više nije imao povjerenje ni u ministre te da će oni (pripadnici Mlade Jugoslavije, op. a.) "pohapsiti ljude, koji su protivu njega, jer da ima na raspolaganju dva miliona vojnika«. HR-HDA-144. SB UO, pov. II. br. 29543/1931.

79 HR-HDA-145. SB ODZ, pov. 2007/1932.

80 HR-HDA-145. SB ODZ, pov. 2007/1932.

81 Konkretno riječ je o Milanu Kramariću, osuđenom 1929. na kaznu teškoga tamnovanja u trajanju od jednoga mjeseca i 5 godina uvjeta. Radi pronevjere novca 1931. taj »neozbiljan i kao nacionalni radnik nepoznat čovjek « završio je u zatvoru, a sreski je načelnik u Ogulinu dopisom upozorio Bansku upravu Savske banovine na mogućnost kompromitiranja rada Mlade Jugoslavije zbog činjenice da takve osobe "nisu sposobne biti pokretač jugoslavenske ideje i širenja državnog i narodnog jedinstva«. HR-HDA-1354. Grupa VII, inv. br. 971.
} 
elementarno osiguravanje egzistencije za sebe i obitelj. Da je tomu moglo biti tako, svjedoči i sastav čelništva podružnice Mlade Jugoslavije u Bobovcu koje su činili predsjednik Mijo Adamović, ranije sudski terećen zbog komunističke propagande, podpredsjednik Ivan Klarić, kažnjavan zbog raspačavanja haesesovskih letaka, te tajnik, trgovac Đuro Kovačević, višestruki dezerter za vrijeme služenja vojnoga roka. ${ }^{82}$ Nije teško zamisliti da se sloboda plaćala doušništvom i potkazivanjem. Izdašnije novčane nagrade vjerojatno su bile namijenjene samo visokopozicioniranim članovima i financiranju najgorih poslova rezerviranih za posebne osobe.

\section{5. (Ne)prikriveni teror}

Domaća i strana javnost bile su dobro upoznate s postupcima članova Mlade Jugoslavije. O tom je, dakako, glasno govoriti smjela isključivo inozemna javnost. ${ }^{83}$ U Zagrebu se i državi stenjalo pod jarmom Zakona o zaštiti javne bezbednosti i poretka u državi iz 1921., zbog posvemašnje psihoze vlasti 1929. protegnutoga na gušenje svake pojave povezane s mogućnošću narušavanja političkoga i socijalnoga poretka Kraljevine. ${ }^{84}$

Jedan od tekstova koji se u to vrijeme pojavio u inozemnoj javnosti bio je članak Una nuova associazione nazionalista opera in Jugoslavia per la serbizzazione rimskoga lista Il giorno d'Italia od 31. siječnja 1931., u kojem je Mlada Jugoslavija prikazana »kao vladino terorističko udruženje naročito osnovano zbog terorističkih atentata protiv političkih ljudi i hrvatskih nacijonalističkih udruženja«. ${ }^{85}$ Tekst je tiskan svega dvadesetak dana prije ubojstva istaknutoga hrvatskog povjesničara, romanopisca i sveučilišnoga profesora Milana Šufflaya, u koje su po svemu sudeći bili upleteni i članovi Mlade Jugoslavije, a prethodio je i napadu "paklenim strojem« na prostorije društva 3 . veljače iste godine. ${ }^{86}$

\footnotetext{
82 HR-HDA-145. SB ODZ, pov. 20175/1932.

83 Iznimku čini već ranije spominjani ilegalni komunistički tisak. Tako je Proleter 1933. u članku "Metode rada policije i mučitelji" kao glavne provoditelje policijskoga nasilja naveo "najvećeg policiskog krvoloka" Bedekovića, njegova nasljednika u fotelji upravitelja zagrebačke policije Mihaldžića te »komandanta vojnog okruga generala Belimarkovića». Osim toga, u tekstu je spomenuta i »fašistička [...] Mlada Jugoslavija«, koja je prema pisanju glasila Centralnoga komiteta Komunističke partije Jugoslavije, uz "leteću brigadu policijskih ubica" pod zapovjedništvom Koste Pećanca iz Beograda organizirala atentat na odvjetnika i pravaškoga političara Milu Budaka. Proleter 9, br. 2 (1933): str. 3-4. O posljednjem usp. Dobrivojević, Državna represija, str. 298-299.

${ }_{84}$ Usp. Slaven Ravlić, Hrvatska enciklopedija: 11: Tr-Ž (Zagreb: Leksikografski zavod Miroslav Krleža, 2009), s. v. Zakon o zaštiti države. O onodobnoj cenzuri tiska usp. Dobrivojević, Državna represija, str. 301-322.

85 HR-HDA-144. SB UO, pov. II. br. 2005/1931. Nažalost, cjeloviti tekst spomenutoga članka unatoč naporima ostao je nedostupan.

${ }^{86}$ HR-HDA-144. SB UO, pov. II. br. 2005/1931. O napadu na sjedište Mlade Jugoslavije »koja je smatrana glavnim uporištem šestojanuarskog režima« usp. Dobrivojević, Državna represija, str. 285.
} 
Organizacija je izrijekom spomenuta i u prosvjednom apelu Međunarodnoj ligi za ljudska prava Alberta Einsteina i Heinricha Manna iz travnja 1931. zbog ubojstva uglednoga hrvatskog intelektualca. Mlada Jugoslavija je i u njem nazvana terorističkom organizacijom koju je vladar izravno naputio na fizičko "odstranjivanje" političkih protivnika te time potaknuo Šufflayevo ubojstvo. U apelu se poimence spominjao ubojica [Branko] Zwerger i njegovi pomagači [Ivan] Brkić, [Josip] Godiler i Marčec, svi pripadnici Mlade Jugoslavije, koji su nekoliko dana prije atentata dogovarali detalje u stanu generala Belimarkovića. ${ }^{87}$ Iako ta verzija događaja, koja se kasnije prenosila u inozemnom tisku, nije bila posve točna, a uvjerljivom se nije činila ni suvremenicima, ${ }^{88}$ ipak je dovoljno govorila o ugledu Mlade Jugoslavije i njezina članstva.

U kolopletu zbivanja koji su obilježili sljedeće događaje i sudske postupke protiv optuženika za Šufflayevo ubojstvo ukratko su se mogle razabrati četiri faze. U prvoj je Bedeković pokušao potpuno odbaciti političke motive nakratko prekinuvši istragu. U drugoj, također Bedekovićevim zamagljivanjem, za ubojstvo je optužen Josip Godler, očito kako bi se sumnja skinula s pravih krivaca, policijskih doušnika i agenata Branka Zwergera i Ljubomira Beloševića. Oni su nedugo nakon atentata poslani u Beč radi izvršenja napada na Pavelićeva suradnika Gustava Perčeca te, vjerojatno, kako bi se blagovremeno sklonili od očiju domaće javnosti. ${ }^{89} \mathrm{U}$ promijenjenim političkim okolnostima suđenje je ponovljeno početkom 1940. godine. Tada su na optuženičkoj klupi sjedili Zwerger, Belošević i Stevo Večerinac. Epilog toga postupka bila je osuda Zwergera za počinjenje ubojstva, Beloševića za pomaganje, a Večerinac je oslobođen. U ponovljenom suđenju provedenom samo za Beloševića u siječnju 1941. i on je oslobođen svih optužbi. ${ }^{90}$

Gotovo da i nema sumnje da su sudionici i izvršitelji atentata na Šufflaya bili povezani s Mladom Jugoslavijom, iako se je njezin, tada već bivši predsjednik Brkić pred sudom 1940. pravdao da Zwerger i Belošević nikada nisu bili članovi društva jer ih "nijesu htjeli primiti«. Doduše, istovremeno je i priznao da su oni kao »organi policije« često zalazili u prostorije društva. ${ }^{91}$ Ćini se da je Brkić u svemu pokušavao ne dovoditi sebe u bilo kakvu vezu s atentatom i optuženicima. Čak je prilikom svjedočenja naveo da je na čin osnivanja Mlade Jugoslavije bio prisiljen od strane tadašnjega upravitelja policije pod prijetnjama optužbi za atentat na izvjesnoga novinara Ristovića. Tada je prema Brkićevim riječima Bedeković izjavio »da će on sam voditi istragu pa da mu ne fali 20 godina robije te da će on zapamtiti tko je Jankić«. ${ }^{92}$

\footnotetext{
87 "Apel Međunarodnoj ligi za ljudska prava," Croatian History, pristupljeno 12. travnja 2019., http:// www.croatianhistory.net/etf/einst.html; Dobrivojević, Državna represija, str. 297.

88 Horvat, Hrvatski panoptikum, str. 252.

89 HR-HDA-397. DN, kns 41/1932; Janjatović, Politički teror u Hrvatskoj 1918.-1935., str. 301-302.

90 HR-HDA-397. DN, kns 41/1932; Dobrivojević, Državna represija, str. 297-298.

91 HR-HDA-397. DN, kns 41/1932; Dobrivojević, Državna represija, str. 297-298.

92 HR-HDA-397. DN, kns 41/1932; Dobrivojević, Državna represija, str. 297-298.
} 
Brkiću svaljivanje krivice na druge, čini se, ipak nije pomoglo. Iako o tom izravnih svjedočenja arhivskih dokumenata nema, čini se da je skupa s još jednim policijskim konfidentom i sudionikom tih događanja Nikolom Jukićem ubijen pod nerazjašnjenim okolnostima početkom 1940. godine. ${ }^{93}$

Jedan od "junaka” Mlade Jugoslavije spomenut je i u Krležinim dnevničko-memoarskim Zapisima sa Tržiča. Iako pisan po sjećanju nakon četrdesetak godina $^{94}$ i iako, pokazalo se je, donekle pogrešan i naizgled dvojbene vjerodostojnosti, taj je tekst možda i najplastičniji prikaz karakterologije i postupaka osoba koje su pod krinkom Mlade Jugoslavije svojedobno štitile Aleksandrov režim. Ugledni je književnik zbog simpatiziranja ljevice, poznato je, imao problema sa zagrebačkom policijom..$^{95}$ Jedna je od osoba koja je dobro poznavala torturu Janka Bedekovića i koja ga je tada smatrala najopasnijim onodobnim policajcem. ${ }^{96}$ Zbog toga, a možda i zbog činjenice da je u to vrijeme živio samo dva kućna broja dalje (Ulica Kraljice Marije br. 32) od sjedišta Mlade Jugoslavije, prema književnikovim je sjećanjima, jednoga dana 1933. ili 1934. (svakako prije marsejskoga atentata) na vratima njegova stana osvanuo izvjesni »Dušan Pijetlović [...] visoki funkcioner 'Mlade Jugoslavije' (mislim čak predsjednik)«, predavši mu opširnu mašinom pisanu autobiografiju. U tom za Mladu Jugoslaviju - koju je i Krleža smatrao "policijskim omladinskim udruženjem» - kompromitirajućem svjedočanstvu Pijetlović se je prikazao svojevrsnim protuobavještajcem i kamufliranim komunističkim agentom. ${ }^{97}$

Taj je besprijekorno odjeveni, pristojni »Dinarac [i] idealna pojava Cvijićeva gorštaka« svojega komunističkog uzora svojevrsnom autobiografskom ispovijedi izvijestio o unutarnjim moralnim i ideološkim lomovima očito tražeći savjet i duhovno iskupljenje za počinjena (ne)djela. Pijetlović je u tekstu ukratko sažeo dotadašnji život, od rođenja u siromašnom (hercegovačkom) kraju, preko potucanja po Slavoniji kao »besprizorno dijete fra Didaka Buntića«, sve do povratka u rodni kraj, "završetka gimnazije«, služenja "po bosanskim kuplerajima i kavanama«, dolaska u Zagreb kao komunistički simpatizer, razočaranja u solidarnost drugova i izdaje, do uhićenja i ležanja u Petrinjskoj, gdje su ga Bedekovićevi agenti izmrcvarili u »lipnju 1929. «. ${ }^{98}$ Otriježnjen batinama, shvativši da je »idealist među barabama i revolucionar među huljama« Pijetlović je promijenio poslodavce. Počeo je $s$ hvatanjem političkih sumnjivaca po noćnim vlakovima, kasnije zbog znanja francuskoga jezika dobivao angažmane na bitnijim špijun-

\footnotetext{
93 Horvat, Hrvatski panoptikum, str. 252.

94 Miroslav Krleža, Zapisi sa Tržiča (Sarajevo: Oslobođenje, 1988), str. 241.

95 Usp. Očak, Krleža - Partija, str. 178, 214. Usp. i Bedekovićev izvještaj o Krleži u: HR-HDA-144. SB UO, pov. II. br. 29370/1931.

96 Enes Čengić, S Krležom iz dana u dan: Balade o životu koji teče (Zagreb: Globus, 1985).

97 Krleža, Zapisi sa Tržičăa, str. 240.

98 Krleža, Zapisi sa Tržiča, str. 242, 244-245.
} 

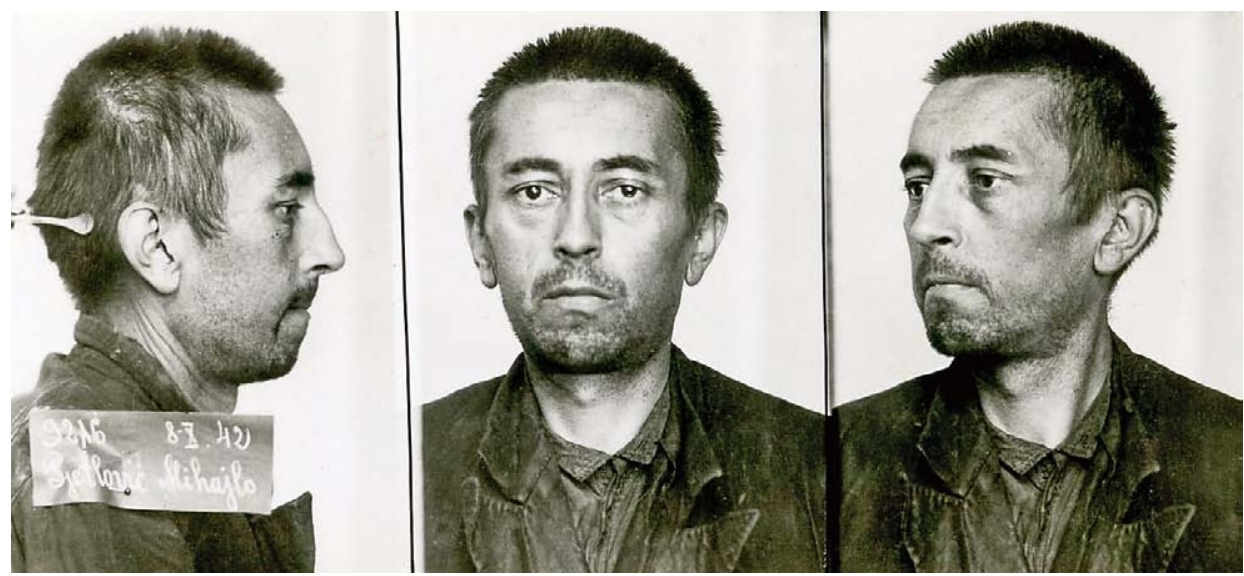

Slika 3. Mihajlo Pjetlović 1942. Ni traga "idealnoj pojavi Cvijićeva gorštaka". HR-HDA-259. ROZ, inv. br. 3691.

skim poslovima u Belgiji i Francuskoj, da bi naposljetku završio u Mladoj Jugoslaviji. ${ }^{99}$

Krležu je gotovo pola stoljeća nakon događaja fascinirala istodobna slaboumnost i dalekovidnost toga "pomalo moralnog kretena [...] iskrenog i smionog srca "koji si je umislio uspjeh u odgonetavanju tajni društva. ${ }^{100} \mathrm{~S}$ gledišta Mlade Jugoslavije osobito je bitno književnikovo prisjećanje Pijetlovićevih detaljnih opisa političkih ubojstava na zagrebačkoj Selskoj cesti, kada je nožem umorio mladoga komunističkog aktivista, u noći prilikom njegova povratka s partijskog sastanka, te u Đakovštini kada je s ortacima likvidirao "glasnoga HSS-ovog korteša, poznatog bukača i narodnog zastupnika «, ${ }^{101}$ zaustavivši ga na njivi tobože tražeći put, zahvalivši za dobrohotnost i upute s pet hitaca u zatiljak. ${ }^{102}$ Među ostalim, prisjetio se i Pijetlovićeva pisanja o audijenciji "petorice-šestorice najviših funkcionera" Mlade Jugoslavije kod Aleksandra na njegovu dvoru na Dedinju, kada je vladar s njima izmijenio nekoliko ljubaznih riječi potaknuvši ih na dalji rad i lojalnost državi, nakon čega je gostima zbog »sprovedenih akcija» osim putnih troškova isplaćeno još po 20.000 dinara ponaosob. ${ }^{103}$

\footnotetext{
99 Krleža, Zapisi sa Tržiča, str. 245.

100 Krleža, Zapisi sa Tržiča, str. 246.

101 Spomenutim događajima u korištenim izvorima, tisku i literaturi nije bilo moguće ući u trag pa se ovi navodi moraju uzeti s oprezom.

102 Krleža, Zapisi sa Tržiča, str. 247.

${ }^{103}$ Krleža, Zapisi sa Tržiča, str. 249.
} 


\section{Iz muzeja Janka Bedekovica u Zagrebu}

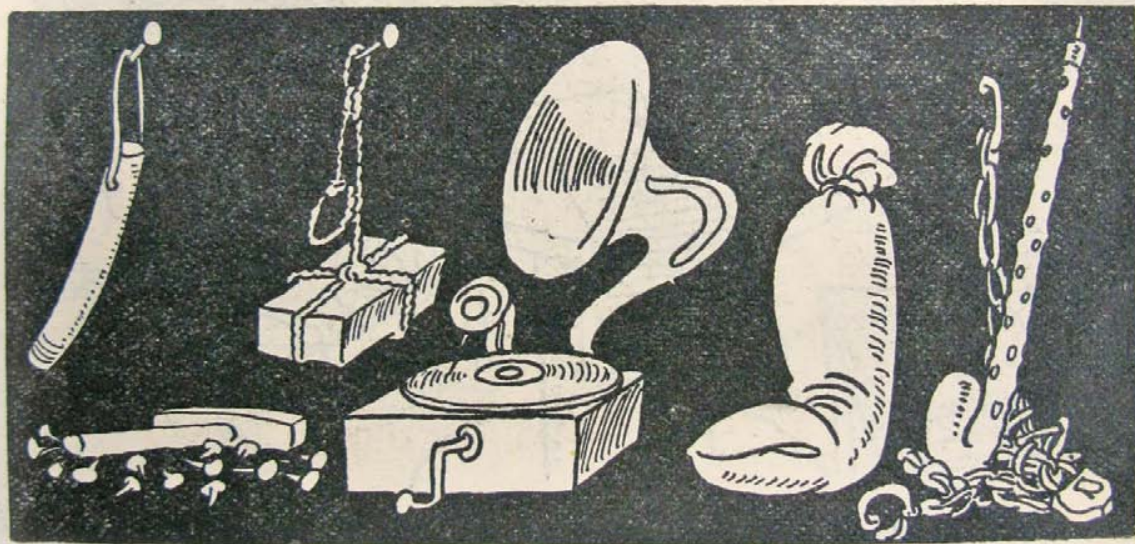

Slika 4. Bedekovićeva "ostavština” u karikaturi Slavka Vereša. Koprive, br. 40 (6. listopada 1939), str. 473.

Krležino memoarsko pisanje, bez obzira na uvijek prisutnu sumnju u varljivost pamćenja, ${ }^{104}$ u konkretnom se slučaju u glavnim crtama pokazalo točnim. Pijetlović je zaista postojao. Doduše, nije se zvao Dušan i nije se prezivao Pijetlović. Pravoga je imena Mihajlo Pjetlović te je zabilježen u arhivskim vrelima. Malo je sumnje da je riječ o istoj osobi. Rođen je u Varcar Vakufu ${ }^{105}$ (ne u Hercegovini, kako je tvrdio Krleža) 11. listopada 1904., od oca Đure i Savke rođ. Stanišić. Bio je pravoslavne vjeroispovijesti, po zanimanju "mehaničarski pomoćnik" sa zadnjom zagrebačkom adresom u Ilici br. 49. Po ustaškim je vlastima uhićen u lipnju 1942. zbog krađe 1.400 dinara iz torbice izvjesne Marije Starčević na željezničkom kolodvoru. Zbog toga je u rujnu osuđen, a krajem listopada interniran u jasenovački logor na odsluženje jednogodišnje kazne. ${ }^{106}$ Iz njega se, najvjerojatnije, nije vratio. Ako je to uopće važno, Pjetlović je imao obitelj, iako je to pred ustaškom policijom zanijekao. ${ }^{107}$ Bio je oženjen Anicom Majer iz Županje (1909.-1980.), s kojom je imao kćer Viktoriju (1930.-?) i sina Mihajla/Mihovila (1932.-1987.). ${ }^{108}$

\footnotetext{
${ }^{104}$ Treba, naime, imati na umu da su Zapisi sa Tržiča posljednja knjiga Krležinih dnevnika, a zapisi o Pijetloviću nastali su u kolovozu 1977., dakle svega četiri godine prije smrti. Krleža, Zapisi sa Tržiča, str. 9. 105 Od 1924. Mrkonjić Grad.

${ }^{106}$ HR-HDA-259. ROZ, inv. br. 3691.

${ }^{107}$ HR-HDA-259. ROZ, inv. br. 3691.

${ }^{108}$ HR-HDA-145. SB ODZ, pov. 26628/1932. Usp. tražilicu pokojnika: “Gradska groblja.” Holding Centar. Pristupljeno 5. travnja 2019. https://www.gradskagroblja.hr/default.aspx?id=382.
} 
Čini se da u Jasenovac nije poslan isključivo zbog krađe. Razlozi su bili dublji, a navodi iz sačuvanoga policijskoga kartona i drugih dokumenata koji o njima govore (ne)izravno potvrđuju i Krležino pisanje. Pjetlović je bio komunistički simpatizer, jedno je vrijeme boravio u Francuskoj, znao je francuski jezik. Zbog komunističke je propagande u lipnju 1927. uhićen u Zagrebu, a 1928. i izgnan iz grada na trogodišnje razdoblje. ${ }^{109}$ Čini se da je upravo u to vrijeme postao policijski doušnik. Naime, usprkos odluci o izgonu i jednogodišnjem robijanju zbog komunističke prošlosti u Travniku i zbog suradnje s poznatim zagrebačkim komunistima Ivanom Krndeljom, Josipom Brozom i dr., 1930. mu je nakon opetovanih molbi "po upravniku dr. Bedekoviću" odobren boravak u Zagrebu nakon što je »obećao usluge [...] radi suzbijanja komunističke propagande«. ${ }^{110}$

Krleža očito nije mnogo griješio. Neke su mu činjenice tijekom vremena jednostavno ishlapjele. Pjetlović nikada nije bio predsjednik ni istaknuti »funkcioner « Mlade Jugoslavije. Dapače, dostupni ga arhivski dokumenti u tom smislu uopće ne spominju. Vjerojatno je bio najobičniji član. Zbog poslova koje je obavljao za policiju nije začudno da je imao više krabulja. Osim u Mladoj Jugoslaviji, formalno je bio suradnik Novoga pokreta karikaturista i novinara Slavka Vereša, vrbujući za tu organizaciju mlade radnike, te "novinar" listova Nova štampa, Zora i Novo doba. ${ }^{111}$ To, dakako, ne znači da navodi u Zapisima s Tržiča nisu vjerodostojni. Možda nisu faktografski posve točni, ali svakako nude jasne obrise vremena i onodobnoga terora Mlade Jugoslavije. O mračnim osobama koje su obavljale nezgodne poslove ionako se oduvijek (pre)malo znalo.

\section{Zaključak}

Ako bismo prethodno štivo nastojali svesti na nekoliko rečenica, morali bismo se voditi za nekoliko činjenica. Zamagljeno, pogrešno nazivano i publicistici slabo poznato društvo, (tobože) osnovano inicijativom upravitelja zagrebačke policije Janka Bedekovića, neprijeporno je postojalo. Nastalo je iznudama, pritiscima i zastrašivanjem bivše haesesovske mladeži nakon uspostave šestosiječanjske diktature u obliku Omladinskoga udruženja Mlada Jugoslavija, formalno osnovanoga 1931. i ukinutoga 1936., odnosno u razdoblju najžešćega režimskog nasilja protiv političkih protivnika Monarhije. Predsjednik udruženja kroz čitavo razdoblje bio je Ivan Brkić, osoba upitnoga moralnog integriteta i promjenjivih ideoloških sklonosti. Temelje društva (uz pridružene policijske agente) činili su njegovi istomišljenici, uglavnom bivši pripadnici podmlatka spomenute političke partije, koji su, što zbog pritiska vlasti, što zbog ishođenja vlastitih materijalnih probitaka, promijenili politički nazor i dotadašnje uzuse javnoga djelovanja otvo-

${ }^{109}$ HR-HDA-145. SB ODZ, pov. 26628/1932.

${ }^{110}$ HR-HDA-145. SB ODZ, pov. 26628/1932.

${ }^{111}$ HR-HDA-145. SB ODZ, pov. 26628/1932. 
reno se stavljajući na stranu Aleksandrova režima. Visokopozicionirani članove Mlade Jugoslavije uglavnom su činile osobe sumnjive, kriminalne prošlosti, hohštapleri, prokazivači, uhode i batinaši zabilježeni u izvještajima onodobnih lokalnih civilnih i vojnih vlasti, koji očito nisu bili dovoljno obaviješteni o svrsi i ciljevima udruge, niti su znali za skrivenu agendu njezina članstva. Društvo je, dakako, formalno djelovalo prema svim pravnim uzusima onodobne države, a promoviranje njegovih ideja provodilo je istoimeno, razmjerno ozbiljno glasilo.

Vanjština ničim nije dala naslutiti naličje. Od samoga je početka, naime, udruga pod krinkom formalnih zadataka imala važnije, prikrivene i vrelima rijetko potkrijepljene zadatke uhođenja, iznuđivanja, zastrašivanja i umorstava političkih protivnika centralističkoga režima. $\mathrm{O}$ spomenutom nam - posve logično - osim memoarskih navoda onodobnih zagrebačkih intelektualaca, nije ostalo puno potvrda. No, ukupnošću sagledavanja sadržaja dostupnih arhivskih izvora u kontekstu onodobne političke klime zabilježene u svjedočanstvima suvremenika, neizravno se i općim uvidom može zaključiti da je Bedeković (a kasnije i njegov nasljednik Mihaldžić) doista posjedovao "posebnu grupu pomagača [koju su činili] razmjerno mladi ljudi koje je neki idealizam nakon rata doveo u polufašističke organizacije da konačno otupivši postanu izvršioci svakog, i najbestijalnijeg naloga «. ${ }^{12}$ Jedino što je o nekom "idealizmu” barem među najviđenijim članovima Mlade Jugoslavije teško moglo biti govora. Bilo kako bilo, bez tih plaćenih, iznuđenih i/ili dobrovoljnih, zaboravljanih i neimenovanih pomagača režima slika jednoga vremena bila bi različitija od one koju danas poznajemo. I, što je još važnije, ruka beogradskih vlastodržaca utjelovljena u osobama upraviteljâ zagrebačkoga redarstva vjerojatno bi slabije udarala po glavama političkih neistomišljenika. Posljedično bi, valjda, i događaji koji su slijedili nakon rasapa onodobne državne zajednice bili drukčiji.

\section{POPIS IZVORA}

\section{Arhivsko gradivo}

\section{Hrvatski državni arhiv}

HR-HDA-144. Savska Banovina. Upravno odjeljenje (SB UO).

HR-HDA-145. Savska Banovina. Odjeljak Upravnog odjeljenja za državnu zaštitu (SB ODZ).

HR-HDA-259. Redarstvena oblast za grad Zagreb (ROZ).

HR-HDA-397. Državno nadodvjetništvo (DN).

HR-HDA-416. Odvjetnička pisarnica Politeo Ivo (OP PI).

\footnotetext{
${ }^{112}$ Horvat, Hrvatski panoptikum, str. 249.
} 
HR-HDA-890. Personalni spisi državnih službenika Zemaljske vlade, Pokrajinske uprave, oblasnih uprava, Savske Banovine, Banovine Hrvatske i ministarstava NDH (Zbirka personalija).

HR-HDA-1353. Građanske stranke i društva (Grupa VI).

HR-HDA-1354. Režimske i reakcionarne organizacije (Grupa VII).

HR-HDA-1359. Teror vladajućeg režima (Grupa XVI).

HR-HDA-1361. Cenzura i zabrana tiska (Grupa XVIII).

HR-HDA-1448. Zbirka mikrofilmova matičnih knjiga i obitelji.

HR-HDA-1561. Služba državne sigurnosti Republičkog sekretarijata za unutrašnje poslove Socijalističke Republike Hrvatske (SDS RSUP-a SRH).

Državni arhiv u Zagrebu

HR-DAZG-10. Gradsko poglavarstvo Zagreb. Zdravstveni odsjek.

Državni arhiv u Osijeku

HR-DAOS-1429. Građanska tiskara Osijek.

\section{Službena glasila i tisak}

Hrvatski list (Osijek), 1925.

Ilustrovani list (Zagreb), 1914.

Mlada Jugoslavija (Zagreb), 1931-1936.

Proleter (Beograd), 1929, 1933. 


\section{Literatura}

"Apel Međunarodnoj ligi za ljudska prava." Croatian History. Pristupljeno 12. travnja 2019. http://www.croatianhistory.net/etf/einst.html.

“Gradska groblja." Holding Centar. Pristupljeno 5. travnja 2019. https:// www.gradskagroblja.hr/default.aspx?id=382.

Bedeković, Janko, Dragutin Šulce. Vježbe na konju za dake, naraštaj $i$ sokolove. Zagreb: Vlastita naklada, 1923.

Bedeković, Janko, Dragutin Šulce. Vježbe na konju za učenice, naraštajke i sokolice. Zagreb: Vlastita naklada, 1923.

Bedeković, Janko. Neiscrpiva građa za pripravu sokolskih prednjaka. Sušak: Tehnički odbor Župe Rijeka, 1922. vak, 2016.

Bogišić, Vlaho. Marginalije o gradovima i ljudima. Zagreb: Naklada Lje-

Bošković, Ivan J. Orjuna: Ideologija i književnost. Zagreb: Hrvatska sveučilišna naklada, 2002.

Brozović, Dalibor, ur. Hrvatska enciklopedija: 3: Da-Fo. Zagreb: Leksikografski zavod Miroslav Krleža, 2001.

Čapo, Hrvoje. Kraljevina čuvara: Represivni aparat monarhističke Jugoslavije na području hrvatskih zemalja (1918.-1941.). Zagreb: Hrvatski institut za povijest, 2015.

Čengić, Enes. S Krležom iz dana u dan: Balade o životu koji teče. Zagreb: Globus, 1985.

Dobrivojević, Ivana. "Policija i žandarmerija u doba šestosiječanjskog režima kralja Aleksandra (1929. - 1935.)." Časopis za suvremenu povijest 38, br. 1 (2006): str. 99-137.

Dobrivojević, Ivana. Državna represija u doba diktature kralja Aleksandra 1929-1935. Beograd: Institut za savremenu istoriju, 2006.

Đurašković, Stevo. "Ideologija Organizacije jugoslovenskih nacionalista." Časopis za suvremenu povijest 43, br. 1 (2011): str. 225-247.

Hercigonja, Rudolf. Lepoglavski vampiri. Zagreb: Merkur, 1919.

Horvat, Josip. Hrvatski panoptikum. Zagreb: Globus, 1982.

Horvat, Josip. Pobuna omladine 1911-1914. Zagreb: Udruga za kulturu Gordogan, 2006.

Horvat, Josip. Živjeti u Hrvatskoj 1900-1941: Zapisci iz nepovrata. Zagreb: Sveučilišna naklada Liber, 1984. 
Janjatović, Bosiljka. Politički teror u Hrvatskoj 1918.-1935. Zagreb: Hrvatski institut za povijest, 2002.

Jonjić, Tomislav. "Proces Hranilović-Soldin: Prilog poznavanju postanka ustaškog pokreta." U Hrvatska između slobode i jugoslavenstva: Zbornik radova sa znanstvenog skupa održanog 8. i 9. siječnja 2009. u Zagrebu, ur. Tomislav Jonjić i Zlatko Matijević, str. 178-180. Zagreb: Zajednica udruga hrvatskih vojnih invalida Domovinskog rata Grada Zagreba, 2009.

Jonjić, Tomislav. "Proces Hranilović-Soldin: Prilog poznavanju postanka ustaškog pokreta." U Hrvatska između slobode i jugoslavenstva: Zbornik radova sa znanstvenog skupa održanog 8. i 9. siječnja 2009. u Zagrebu, ur. Tomislav Jonjić i Zlatko Matijević, str. 167-196. Zagreb: Zajednica udruga hrvatskih vojnih invalida Domovinskog rata Grada Zagreba, 2009. 1928.

Jovanović, Rajko. Glavnjača kao sistem. Zagreb: Izdanje Zaštite čovjeka,

Kisić-Kolanović, Nada. Ivo Politeo: Povijest, intelektualci, odvjetništvo 1887.-1956. Zagreb: Hrvatski institut za povijest, 2015.

Kokanović, Dunja. "Izašao novi lokalni list u Brodu." Brodportal (31. prosinca 2016). Pristupljeno 27. ožujka 2019. http://www.brodportal.hr/clanak/ izasao-novi-lokalni-list-u-brodu-14542.

Kraus, Zigmund. "Iz Jugoslovenskih Glavnjača: Jezoviti prikaz mučenja S. Krausa." U Stara Jugoslavija i komunizam: Zakoni, sudovi, zakoni i logori u staroj Jugoslaviji protiv komunista, ur. Ivan Ribar, str. 187-190. Zagreb: Stvarnost, 1967.

Krizman, Bogdan. Ante Pavelić i ustaše. Zagreb: Globus, 1978.

Krleža, Miroslav. Zapisi sa Tržiča. Sarajevo: Oslobođenje, 1988.

Očak, Ivan. Krleža - Partija: Miroslav Krleža u radničkom i komunističkom pokretu 1917-1941. Zagreb: Spektar, 1982.

Oreški, Vlado, Milan Nikolić. Sibirski pečat. Zagreb: Sveučilišna naklada Liber, 1983.

Pravila Omladinskog društva "Mlada Jugoslavija". Zagreb: Tiskara Merkantile, 1930.

Ravlić, Slaven, ur. Hrvatska enciklopedija: 11: Tr-Ž. Zagreb: Leksikografski zavod Miroslav Krleža, 2009.

Ravlić, Slaven, ur. Hrvatska enciklopedija: 8: O-Pre. Zagreb: Leksikografski zavod Miroslav Krleža, 2006.

Sršan, Stjepan, Vilim Matić. Zavičajnici grada Osijeka 1901.-1946. Osijek: Državni arhiv u Osijeku, 2003.

Stipančević, Mario. "Vampir iz Petrinjske: Obris portreta Janka Bedekovića." Gordogan 15, br. 35-36 (2017): str. 104-128. 
Summary

\section{YOUNG YUGOSLAVIA - THE TERRORIST BRANCH OFFICE OF ZAGREB'S POLICE}

A certain youth society established as a police cover-up organization for carrying out acts of spying, extortion, threats, intimidation and murder of political opponents of the Yugoslav power-holders in the 1930s was rarely mentioned in historiographical texts. The components of its existence were almost completely blurred in these works, from its name, structure, membership, ideology, to its aims and actions. The article tried to overcome this by shedding light on the personality of the former director of Zagreb's police and King Alexander's favourite, dr. Janko Bedeković, revealing him as the initiator and the direct financier of 'The Young Yugoslavia' youth society - the association that under the usual guise of the state-spread organization whose intention was to promote the Yugoslav idea among the youth hid the grimy side of carrying out direct police orders in dealing with political opponents. The terror carried out by the members of 'The Young Yugoslavia', just like the period of Bedeković's tenure as the head of Zagreb's police, remained deeply rooted into the collective memory of the Croatian society of that time. The extorted criminals, bullies and swindlers protected by the membership card of that society had, under the guise of the Yugoslav idea and the fight for a unified national state, free hands to satiate their personal and morally questionable urges. This is perhaps the first occasion that their mention is based on archival sources.

Keywords: 'The Young Yugoslavia' youth society; Janko Bedekovic'; Kingdom of Yugoslavia; political terror 